CURRENT AFRICAN ISSUES 19

\title{
Human Rights and Homosexuality in Southern Africa
}

by

Chris Dunton and Mai Palmberg

Second, expanded edition 
The opinions expressed in this text are those of the authors and do not necessarily reflect the views of Nordiska Afrikainstitutet.

ISSN $\quad 0280-2171$

ISBN $91-7106-402-8$

(c) the authors and Nordiska Afrikainstitutet 


\section{Contents}

$\begin{array}{lr}\text { Foreword } & 5\end{array}$

Some Basic Terms 6

Zimbabwe-The Book Fair Drama 1995

Zimbabwe-The Second Book Fair Drama $1996 \quad 17$

African Voices for and against Homosexuality 24

Namibia-Ministers and Activists 29

Botswana-Sharing the Blanket $\quad 32$

South Africa-The Bill of Rights Debate 34

Homosexuality and the Law-A Global Overview 39

APPENDICES

1. AIDS and Homosexuality, Getting the Facts Straight 46

2. Address List to human rights organisations; websites and 47 organisations for gay and lesbian rights in southern Africa 


\section{Foreword}

On May 8, 1996 South Africa adopted a new constitution, which in its Bill of Rights prohibits discrimination on grounds of sexual orientation. South Africa was the first country in the world to adopt such a sexual orientation clause in its constitution. This is an important stride in the development of a human rights culture.

The title of this booklet refers to human rights in general rather than to gay and lesbian rights, specifically. This is deliberate. Abuse and discrimination are unacceptable whether they are directed towards gays and lesbians, heterosexual women, children, members of minority ethnic groups, whoever. This being the case, the inclusion in the new South African constitution of a clause prohibiting discrimination on the grounds of sexual orientation should be a cause of celebration to everyone. And the campaign of the Zimbabwean leadership against homosexuals should, for the same reason, be a cause of concern to everyone.

This booklet was prompted by events at the Zimbabwe International Book Fair of 1995, when one of the exhibitors, the organisation Gays and Lesbians of Zimbabwe (GALZ), were prevented from taking part. Their exclusion was carried out under instructions from the Zimbabwean government. President Robert Mugabe himself made a speech in which he was brutally dismissive of gays and lesbians and of the very idea that this community should be allowed human rights. Since then Mugabe has reiterated his views on a number of occasions, in terms that invite outright discrimination against gays and lesbians. His campaign has opened up a wide debate on homosexuality and human rights.
There was a new confrontation at the Zimbabwe International Book Fair of 1996. This time the clash was also between the government and civil society, as the book fair organisers had taken a principled stand on GALZ' right to take part. The revised edition of this booklet includes a first-hand report on the 1996 book fair drama.

We feel that in the context of Mugabe's intervention and in the context of vigorous efforts to assert their rights, gays and lesbians in southern Africa have arrived at a crucial historical moment in the development of their community. As with all sexuality, however, homosexuality is seldom discussed openly in southern Africa. We hope our booklet will have a documentary and informative function, and that it will provide a resource for human rights organisations and for gay and lesbian activists, hoping to stimulate awareness and debate.

We wish to thank the Swedish NGO Foundation for Human Rights for their financial support for this documentation.

We also wish to thank Pieter van Gylswyk for help in locating interventions in the southern African debate, Björn skolander for his steady stream of useful material, and Peter Nobel, Christer Krokfors, Ingrid Fandrych and Ingela Ösgård for constructive criticism of the drafts. For the assistance with material at the 1996 Book Fair we want to extend our deep gratitude to all those who generously shared their time, information and insights.

A final note: We have used footnotes to provide sources for any reader who wishes to check our quotations. We shall be very happy to receive comments and to provide 


$\begin{array}{ll}\text { more information on source material to any reader who requests this. } & \\ & \\ \text { Chris Dunton } & \text { Mai Palmberg } \\ \text { Dept. of English } & \text { The Nordic Africa Institute } \\ \text { University of the North West } & \text { Box } 1703 \\ \text { Private Bag X2046 } & 75147 \text { Uppsala } \\ \text { Mmabatho } 2735 & \text { Sweden } \\ \text { South Africa } & \text { E-mail: mai.palmberg@nai.uu.se }\end{array}$




\section{Some Basic Terms}

\section{Terms relating to the discourse on homosexuality}

\begin{tabular}{|c|c|}
\hline $\begin{array}{l}\text { homosexuality } \\
\text { homophobia }\end{array}$ & $\begin{array}{l}\text { Sexual orientation towards members of one's own sex } \\
\text { Intense dislike, hatred or fear of homosexuals and } \\
\text { homosexuality (also as adjective: 'homophobic') }\end{array}$ \\
\hline omosexual behaviour & $\begin{array}{l}\text { Engaging in sexual acts with members of the same sex } \\
\text { (but not necessarily seeing oneself as having a } \\
\text { homosexual identity - see identity) }\end{array}$ \\
\hline omosexual & $\begin{array}{l}\text { A person who is sexually attracted to members of the } \\
\text { same sex-used as both as a noun ('he is a } \\
\text { homosexual') and an adjective ('he is homosexual')- } \\
\text { see gay }\end{array}$ \\
\hline ay & $\begin{array}{l}\text { Homosexual (as adjective: "a gay Namibian"), or as a } \\
\text { noun in plural ('gays"). Sometimes used only for } \\
\text { male homosexuals, as in the expression 'gay and } \\
\text { lesbian'-see lesbian }\end{array}$ \\
\hline Lesbian & A woman who is attracted sexually to other women \\
\hline isexuality & $\begin{array}{l}\text { Attraction to, and/or engaging in sexual acts with, } \\
\text { members of both one's own and the opposite sex }\end{array}$ \\
\hline identity & $\begin{array}{l}\text { The sense a person has of her/his own individual } \\
\text { nature and personality and of the way this leads the } \\
\text { individual to identify with specific groups of } \\
\text { people (for instance, by way of nationality, } \\
\text { language group or sexual orientation). Most people } \\
\text { see themselves as having a set of different } \\
\text { identities, for example as woman and South African } \\
\text { and coloured and teacher. Acknowledging a gay or } \\
\text { homosexual identity can mean identifying as a member } \\
\text { of a gay or lesbian community-see community }\end{array}$ \\
\hline $\begin{array}{l}\text { gay and lesbian } \\
\text { community }\end{array}$ & $\begin{array}{l}\text { groups of gays and lesbians for whom their gay or } \\
\text { lesbian identity is central to their personality, } \\
\text { and who have grouped together with others for } \\
\text { social, counselling or lobbying purposes }\end{array}$ \\
\hline sodomy & $\begin{array}{l}\text { A concept used to cover all forms of sex considered } \\
\text { perverse; sometimes used for male homosexuality, } \\
\text { sometimes for anal sex, sometimes for sexual acts } \\
\text { with animals }\end{array}$ \\
\hline bestiality & Having sexual intercourse with animals \\
\hline edophilia & Adults having sexual intercourse with children \\
\hline AIDS & $\begin{array}{l}\text { Acquired Immune-Deficiency syndrome, a sexually } \\
\text { transmitted disease which is transmitted by the HIV- } \\
\text { virus (see appendix on } A I D S \text { ) }\end{array}$ \\
\hline
\end{tabular}

\section{Terms relating to the discourse on human rights}

Human rights

UN Universal

Declaration

of Human Rights

Mandatory
Rights that people have as individuals

Adopted in 1948 by the General Assembly of the then newly formed United Nations, this outlines a set of rights for individuals, groups, and nations. It is a recommendation to the member states, not a mandatory and binding document

obligatory, binding to the members or signatories 
Constitution

Discrimination

Bill of rights

Common law

Eurocentrism

Afrocentrism

Universality
A basic law setting down principles that must be followed in the political system, and to which all legislation must conform. Most, but not all countries have written constitutions

Denying equal rights and equal treatment to individuals, usually on the grounds of their group identity, such as blacks, women, foreigners or homosexuals

A legal document setting down fundamental rights of the citizens of a country or members of a specified community

The unwritten laws and rules that apply in a particular society. In Africa 'common law' refers to rules and regulations that are considered or claimed to be traditional to a certain community, usually an ethnic community

A term used to describe, in a negative sense, import of ideas from Europe (or the West) and/or the ideas that ideas and institutions as they are perceived in the Western countries is the standard and norm for the whole world

A term used to describe the rejection of Eurocentrism and the substitution for this of Africa-centred standards, norms and concepts

A universal right applies everywhere, regardless of country, religion, ethnicity etc., as the UN Declaration of Human Rights. 


\section{Zimbabwe-The Book Fair Drama 1995}

The 1995 theme for the Zimbabwe International Book Fair (ZIBF) was "Human rights and justice". The emphasis on human rights might have gone unnoticed by the international media, had it not been for the richly ironic drama created by the Zimbabwean government.

on the demand of government one of the smaller exhibitors, the Gays and Lesbians of Zimbabwe, was at the last minute excluded from the fair. The African Book Publishing Record headlined their report: ${ }^{1}$

'Human rights' theme at the Zimbabwe International Book Fair turns into fiasco.

The exclusion and the attack on gays by president Mugabe propelled a vigorous debate on the extent and meaning of human rights, the rights and existence of homosexuals, the power of government over such events as the book fair, the meaning and origins of African tradition, and the relationship between presumed African and foreign values.

The main questions raised in this discussion were: Are gay rights a legitimate part of human rights? Does the universality of human rights apply? Is homosexuality 'natural' or an imported Western phenomenon? Does the restriction of gay rights signal a threat to other rights and to freedom of expression?

The drama of the book fair events forced these issues on to the agenda in the whole of southern Africa. Only in South Africa had there been an open debate on homosexuality long before the Zimbabwe book fair drama in 1995. South Africa also had a growing gay community, people who saw themselves as having a gay or lesbian identity. This had emerged

1 The African Book Publishing Record, Vol. XXI, No.3 1995, p. 167 on the public scene in 1968 and was first apolitical, and concerned only with its own single-issue activities. But towards the end of the eighties a number of gay and lesbian organisations emerged in South Africa who aligned themselves with the ANC's Freedom Charter and asserted gay rights as human rights. ${ }^{2}$

A public debate on homosexuality had started in Zimbabwe in 1994 after Gays and Lesbians of Zimbabwe (GALZ) had put an advertisement in the Daily Gazette for its counselling services. Until then, from its founding in 1989, it had lived a quiet life as a support group and social club for the small but growing gay and lesbian community in Zimbabwe. This debate raged from January 1994 to mid-1994 when suddenly all media fell quiet. Rumour had it that the government had placed an embargo on all gay related subjects. ${ }^{3}$ Thanks to president Mugabe, the silence was not to last.

\section{The GALZ booth and its prohibition}

Preparations for the book fair were well under way in July 1995. It was again going to be held in the city gardens of Harare, a park that was prohibited for blacks during the white minority regime before independence in 1980 .

When the exhibition was about to open the Gays and Lesbians of Zimbabwe (GALZ), one of the smallest of the 240 exhibitors, was barred from taking part by government

\footnotetext{
${ }^{2}$ Gevisser, Mark \& Edwin Cameron eds., Defiant desire. Gay and lesbian lives in South Africa, Ravan Press, Johannesburg 1994, p. 63.

${ }^{3}$ Information from Stephen van Breda, Harare.
} 
order. The ban and president Mugabe's outburst against homosexuals became big news in southern Africa and all over the world. But the issue was not entirely new to the organisers and some of the exhibitors.

GALZ had wanted to exhibit and advertise its literature on the legal and constitutional aspects of gay rights. A sticker produced by GALZ with the text "Don't hate! Tolerate" made an appeal to the general public, and was hardly a provocative self-assertion. But earlier in the year GALZ had been denied registration, and the Minister of Home Affairs, Dumiso Dabengwa, had declared that homosexuality is abnormal and would not be allowed in Zimbabwe. ${ }^{1}$

In March the Executive Director of the Zimbabwe International Book Fair (ZIBF), Trish Mbanga, at a meeting in Johannesburg to solicit South African publishers' support for the fair, reported that the security forces had intimidated GALZ after they had applied and paid for a stand with ZIBF acceptance. She intimated that the ZIBF trustees were inclined to refuse their application to avert disruption of the fair. The South African publishers in the meeting felt strongly that this would compromise their participation, and a letter was written supporting the acceptance of GALZ' participation. ${ }^{2}$ The matter seemed to be settled.

One week before the book fair the book fair organisers received a letter (July 24) from the Zimbabwe Director of Information, Bornwell Chakaodza, with the following content:

The government is dismayed and shocked by the decision of the Book Fair Trustees to allow the so called Gays and Lesbians of Zimbabwe (GALZ) to participate in the Zimbabwe

\footnotetext{
${ }^{1}$ Mmegi/The Reporter (Gaborone), Vol. 12, No. 32, 18-24 Aug. 1995.

2 Report to the PASA executive by Stephen Johnson, 16 Aug. 1995.
}

International Book Fair (ZIBF) which will be officially opened by the President of the Republic of Zimbabwe, His Excellency Cde R.G. Mugabe. The Government strongly objects to the presence of the GALZ stand at the Book Fair which has the effect of giving acceptance and legitimacy to GALZ.

Whilst acknowledging the dynamic nature of culture, the fact still remains that both Zimbabwean society and government do not accept the public display of homosexual literature and material. The Trustees of the Book Fair should not, therefore, force the values of gays and lesbians onto the Zimbabwean culture.

In the interest of continued cooperation with the government, please, withdraw the participation of GALZ at this public event. ${ }^{3}$

The trustees contacted GALZ to explain the situation and suggested it pull out, which GALZ refused to do. The ZIBF then announced that "with the greatest regret" it found itself having no option but to withdraw its permission for GALZ to participate. While doing so it pointed out that ..."its decision in no way compromises its commitment to freedom of expression". " In a statement a few days later to all ZIBF participants the trust explained:

The Trustees were faced with a very difficult and painful decision. We had made our own position clear in the original acceptance. But we had to face not only withdrawal of state participation and support but also the very real possibility of further state action or disruption of the Fair itself. With great reluctance and acting under severe constraint,

\footnotetext{
3 Letter to Mrs Trish Mbanga, Executive Director of the Zimbabwe International Book Fair from the Ministry of Information, Posts and Telecommunications, Director of Information Bornwell Chakaodza, July 24, 1995.

d ZIBF statement, July 28, 1995
} 
we withdrew acceptance of GALZ' participation. ${ }^{1}$

An "Indaba" on Human Rights and Freedom of Expression had been organised to precede the book fair. When news of the expulsion reached the participants a motion was moved by Nobel Prize winner Nadine Gordimer deploring the Zimbabwe government's exclusion of GALZ. Along with another resolution condemning the Nigerian Government's abuse of human rights it was supported by all participants at the Indaba, which also included Nobel Prize winner Wole Soyinka, and several other African writers and human rights activists. It urged

that the ban be withdrawn and that the human rights principle on which we accepted to participate in this Indaba be honoured. ${ }^{2}$

Nadine Gordimer told journalists:

I am appalled. It is very strange to be standing under the banner of freedom of expression while a group has been denied the very right to express themselves at the book fair... We are saying that human rights are universal rights, but it seems there is a double standard. 3

"Freedom of expression is tolerating things we don't really like", Andrew Morrison, a university lecturer and member of GALZ, observed. ${ }^{4}$

\section{Mugabe's opening speech}

At the official opening of the book fair on August 1 the president of Zimbabwe, Robert Mugabe did not exactly play down the issue, but guaranteed international attention to what the New York Times called "a

\footnotetext{
1 31st Statement to all ZIBF95 participants, Harare, July 1995.

2 Resolution passed at the Book Fair Indaba July 28, 1995.

3 The Star (Johannesburg), July 29, 1995

4 Lewis Macipisa, "Human Rights:

President Lashes out at Gays", IPS

Africa, Aug. 18, 1995.
}

stinging attack on homosexuals" ${ }^{5}$. Mugabe said:

Supporting persons who believe that the denial of their alleged rights to have sex in public is a violation of their human rights formed as association in defence and protection of it and proceeded to write booklets and other forms of literature on the subject of their rights. Is any sane government which is a protector of society's moral values expected to countenance their accessions?

I find it extremely outrageous and repugnant to my human conscience that such immoral and repulsive organisations, like those of homosexuals who offend both against the law of nature and the morals of religious beliefs espoused by our society, should have any advocates in our midst and even elsewhere in the world.

If we accept homosexuality as a right, as is being argued by the association of sodomists and sexual perverts, what moral fibre shall our society ever have to deny organised drug addicts, or even those given to bestiality, the rights they might claim and allege they possess under the rubrics of individual freedom and human rights, including the freedom of the Press to write, publish and publicise their literature on them?

The nature of GALZ and their objective in participating in the book fair had apparently escaped the president. They had wanted to advertise and promote their counselling service and their view that gay rights were in fact one aspect of human rights. They had never wanted to exhibit pornography, nor had they ever suggested or implied that homosexuals wished to have sex in public or considered this to be their right.

At a press conference after the opening president Mugabe said of homosexuals:

I don't believe they should have any rights at all.

5 The New York Times (New York), Aug. 2, 1995 
I hope the time never will come when we all want to reverse nature and men bear children. ${ }^{1}$

When asked about the risks that the crisis could mark the end of the book fair in Zimbabwe, he snapped: "Is the book fair based on sodomy?"

On opening day secret police in plain clothes had visited the fair to tear down posters protesting against GALZ' exclusion. They were stopped when they attempted to tear down posters at the stands of Amnesty International and a Londonbased publishing company. The former called the remarks by President Mugabe "a heavy-handed attack upon the basic freedom of expression". ${ }^{2}$

\section{The book fair in crisis}

One of the trustees later replied to accusations that they had promptly bowed to the government demand:

\begin{abstract}
Seven days passed between the directive and the trust's decision. Agonising debates took place during this time. The trust's primary concern was the future of ZIBF. It was therefore with great reluctance that the trustees decided to withdraw their acceptance of the application by GALZ to take a stand at the fair.
\end{abstract}

This decision has been seen by some as the ZIBF Trust's immediate capitulation to government interference. This was most definitely not the case. The trust believes very strongly that this is a unique issue. It is not simply a question of say, gay rights this year, women's rights next year. It needs to be remembered that it has taken many years for homosexuality to be accepted in the West. It is not reasonable to expect it to be quickly accepted in zimbabwe.

The trust displayed a statement in the exhibition space that was to have been occupied by GALZ. Subsequently, other organisations issued statements in support of GALZ' right to rent space at the fair, and these, too, were displayed. Government ministers

\footnotetext{
${ }^{1}$ South African News Agency SAPA, BBC Summary of World Broadcasts, Aug. 3, 1995

2 The New York Times, Aug. 6, 1995
}

and security personnel demanded they be removed. The trust refused.

GALZ members attended the fair as individuals and discussed the issue with members of the public who had become aware of it as a result of the publicity. Government directives to the press have ensured that homosexuality is not even mentioned. The ZIBF trust ensured that the issue was discussed.

If the ZIBF were closed, we as trustees would have abrogated our primary responsibility-to promote an informed reading and book-buying public. Ironically, literature on homosexuality could be found on the stands of many mainstream commercial publishers. Without ZIBF, that, too, would be lost. ${ }^{3}$

Two trustees of the Zimbabwe Book Fair Trust, Sue MacMillan and Barbara Keene had already resigned from the 18-member board in protest against the way the board had handled the issue. With the final clamp-down on GALZ two honorary trustees resigned in protest against the Zimbabwe government's action. They were Hugh Lewin and Hans Zell. The latter had been one of the initiators of the Zimbabwe Book Fair in the early 1980s. He expressed his support for the book fair in the future, but added:

...although well aware of the
sensibilities of the issue and
practice of homosexuality in an
African context... to deny gays and
lesbians of their right to exhibit
was a shameful act of intolerance...
and it is particularly ironic and
preposterous when the theme of ZIBF
95 was human rights and justice.

Another sign of crisis for the book fair was the announcement on its opening day that exploratory talks on a future joint southern African book fair had been suspended by the executive committee of the Publishers Association of South

\footnotetext{
${ }^{3}$ Roger String "We agonised about excluding Zim's gays", Mail \& Guardian (Johannesburg), Aug. 18, 1995

${ }^{4}$ The African Book Publishing Record, Vol. XXI, No. 3 1995, p. 167
} 
Africa (PASA). They referred both to the Zim-babwean government's action, and to the South African (interim) constitution, which in its bill of rights prohibited discrimination on account of sexual orientation. Referring to "South Africa's own history of discrimination and censorship" PASA felt compelled to "warn of the dangerous consequences of applying authoritarian measures such as these." PASA also recommended to its member publishing companies to reconsider participation at the next fair "unless the government of Zimbabwe guarantees the freedom to publish and display works of any kind." ${ }^{1}$

Since the South African publishers were the numerically second largest group after the Zimbabwean exhibitors, their withdrawal would be a major blow to the fair. It was even suggested by the Sunday Mail that the "attempt to manufacture the gays and lesbians of Zimbabwe as a burning human rights issue" was nothing but "a deliberate provocation to justify the launching of a campaign by a fifth column in Zimbabwe and their allies abroad to have the Book Fair event hosted elsewhere in the region." ${ }^{2}$ This allegation was vehemently denied by PASA.

\section{The protests and civil society}

The most striking feature of the book fair drama was the strong response it evoked in southern Africa, and elsewhere.

Amnesty International condemned the government action in a statement at the beginning of the book fair:

This is a heavy-handed attack upon the fundamental human right to freedom of expression, to which Zimbabwean government is ostensibly committed under its international

\footnotetext{
${ }^{1}$ Press release from the Executive Committee of the Publishers' Association of South Africa (PASA), 1 August 1995.

2 The Sunday Mail (Harare), "Comment: Burning Issues", Aug. 6, 1995.
}

legal obligations. It sits ill with the theme of this year's Book Fair, which is Human Rights and Justice, that GALZ is being denied the right to advocate and promote the rights of gays and lesbians. ${ }^{3}$

The harshest criticism of Mugabe in the region came from South Africa. On Friday August 11 about a hundred people demonstrated outside the Zimbabwe trade mission in sauer Street in central Johannesburg in protest against Mugabe's views on homosexuals. "Vorster said blacks have no rights. Mugabe says gays have no rights", was the text of one of the placards. The organiser, the National Coalition for Gay and Lesbian Equality, reported that they had received messages of support from Lawyers for Human Rights, Black Sash, the AIDS consortium, the Women's National Coalition, and the Centre for Applied Legal Studies at the University of the Witwatersrand. ${ }^{4}$

When president Mugabe arrived on Aug. 26, 1995 at the Jan Smuts Airport near Johannesburg for a meeting of the Southern African Development Community (SADC), he was met by demonstrators with placards such as "Zimbabwe needs a queen".

Peter Vale, professor of Southern African Studies at the University of Western Cape, saw the protests as something new in southern African politics:

\begin{abstract}
...for the first time in the region's history, an interest group in another country has put pressure on the leader of a majority-ruled government.

This is an entirely new development, and it holds enormous potential for the growth of civil society in southern Africa. ${ }^{5}$
\end{abstract}

Vale refers to the strong NGO presence in Beijing at the United Nations conference on women as a

\footnotetext{
3 Amnesty International, July 31, 1995.

4 Southscan (London), Aug. 18, 1995.

${ }^{5}$ Peter Vale, "Gay people changed the region", Mail \& Guardian, Oct. 6-12, 1995.
} 
model which "has helped us understand the power of collective consciousness across international borders" :

There is an important lesson for the region in all this. As links between civil society in Southern Africa deepen, a central goal should be to create an independent voice in the affairs of the region. To achieve its political goals, it must be sufficiently strong to rival the 'government-speak' which, until now, has dominated the discussion on Southern Africa's future.

One could add that the model by which the United Nations invites NGOs to set up an alternative conference to interact with and place pressure on the official proceedings of big international conferences was initiated with the 1992 UN Conference on Environment and Development. Peter Vale recommends that civil society sets up its own stall when the Southern African Development Community or the Organisation of African Unity meets.

\section{Cautious protests in Zimbabwe}

The Zimbabwean protests were generally weak, and even fewer were printed in the Zimbabwean media. The Zimbabwe Human Rights Organisation and the Catholic Commission for Justice and Peace issued critical statements. Ozias Tungwarara, executive director of the Zimbabwe Human Rights Organisation was quoted in The Namibian as saying of Mugabe:

He took the populist approach. He knew he was on safe ground domestically. Most of our people will say that homosexuality is abhorrent. ${ }^{1}$

A lawyer at the University of Zimbabwe, Derek Matyszak, was quoted in the Windhoek Advertiser as saying that there is a valid comparison between discrimination faced by blacks because of their skin colour and prejudice against gays. He pointed out that most people would see the

\footnotetext{
${ }^{1}$ Quoted in The Namibian (Windhoek), Aug. 21, 1995.
}

prohibition of interracial sex, as in apartheid South Africa or precivil rights United States, as "an abhorrent violation of an individual's human rights", but that

many of the same people still need to be convinced that it is equally cruel and a violation of human rights to keep a loving couple apart and to discriminate against them on the basis of their sexual orientation ${ }^{2}$

A political scientist at the University of Zimbabwe, John Makumbe, was quoted in the South African Star saying about president Mugabe that

...the outbursts against Zimbabwe's gays serve his purpose of diverting attention from his own closet where he is living with his former secretary and their two children. He should be the last one to talk about morals. ${ }^{3}$

Cautiously worded support for homosexuals was expressed by Edwin Sakala of the Zimbabwe Catholic Commission for Human Rights:

\begin{abstract}
It is my right if I decide to walk naked in public. But such an act constitutes public indecency, and the law will have to take its course. Gays and lesbians have the right to privacy but if they display it (their sexuality) in public, it becomes public indecency... The police are infringing homosexuals' rights when they invade their homes. Homosexuality is not a crime. ${ }^{4}$
\end{abstract}

\section{Mugabe's rearguard}

Two weeks after the book fair a meeting of five hundred members of the ruling ZANU-PF party was organised by the Women's League, which in a statement said:.

We are Zimbabweans and we have a culture for Zimbabweans to preserve. As mothers and custodians of our heritage, we stand solidly behind our

\footnotetext{
2 SAPA-AFP, in The Windhoek Advertiser Aug. 23, 1995

3 The Star, Aug. 28, 1995.

4 Quoted in Free Press, Media Institute of Southern Africa (Windhoek), 5/1995, p. 12 .
} 

$\begin{aligned} & \text { president and leader on his } \\ & \text { unflinching }\end{aligned}$
stand against homosexuality. Human rights should not be allowed to dehumanise us. Do not be deceived. Neither the sexually immoral nor idolaters nor adulterous nor male prostitutes nor homosexual offenders nor the greedy nor drunkards will inherit the kingdom of God. ${ }^{1}$

The demonstrators carried placards with texts such as "God created Adam and Eve and not Adam and Steve".

The Sunday News praised President Mugabe's "bold denunciation of homosexuals as undesirable sodomites" and rejoiced that "university students and the ZANU-PF Women's League have at last found something in common to agree on". ${ }^{2}$

The Chronicle in Harare presented the issue as one of incompatibility between African and foreign values, just as Robert Mugabe a few years earlier had dismissed homosexuality as "a white problem" ${ }^{3}$ :

Painful experience reminds us Zimbabweans and all other Africans on the continent of moves orchestrated by colonialists to wipe out anything that had to do with African culture as constituted mainly by our customs and traditions. This was done in ways that included the imposition of foreign languages on our indigenous languages to try to superimpose cultural values on our own values.

Many years after decolonisation attempts to wipe out what is left of our cultural values are still being made-and made with a vengeance in some cases, witness the shrill outcries over the refusal by the Government to allow the Gays and Lesbians of Zimbabwe to peddle its ideas by exhibiting at the recent Zimbabwe International Book Fair in Harare -a refusal that all Africans who cherish their cultural identityor what remains of it-should support unflinchingly. ${ }^{4}$

1 Quoted in IPS Africa, Aug. 18, 1995.

2 The Sunday News, 3 Sept. 1995.

3 The New York Times, Aug. 6, 1995

4 The Chronicle (Harare), Aug. 9, 1995

\section{Mugabe persists}

Mugabe continued his attacks on gays in Zimbabwe after the book fair. Speaking on Heroes' Day on August 11 he urged churches and others to ensure that society was not distracted from traditional values, and added:

It degrades human dignity. It's unnatural and there is no question ever of allowing these people to behave worse than dogs and pigs. 5

Departing from his prepared speech, Mugabe said:

What we are being persuaded to accept is sub-animal behaviour and we will never allow it here. If you see people parading themselves as lesbians and gays, arrest them and hand them over to the police. ${ }^{6}$

Zimbabwean law is in fact unclear about the status of homosexuals, but under common law "unnatural sexual acts" are illegal, with penalties ranging up to ten years' imprisonment (see the appendix on homosexuality and the law; a global overview).

When he heard about protest demonstrations at Zimbabwean diplomatic and trade missions in Britain and South Africa, Mugabe told an Anglican women's group on August 16 :

They can demonstrate, but if they come here we will throw them in jail.

Meanwhile, a letter was sent to president Mugabe from 70 US Congressmen, 68 Democrats and two Republicans, led by Barney Frank who accused the president of bigotry and pointed to the South African constitutional clause against discrimination on the basis of

5 Reuters news agency, published in the Globe \& Mail (Toronto), Aug. 12,1995, and The Herald (Harare), Aug. 12, 1995.

${ }^{6}$ Associated Press and Reuters news service, as broadcast on "This Way Out", program \# 386, distributed Aug. 21, 1995.

7 AP and Reuters news service 
sexual orientation. The statement, carried by the independent weekly, the Financial Gazette in Harare, had said:

Attacking decent individuals who are fully respectful of the rights of others, who are productive and responsible citizens but who happen to be gay or lesbian is wrong. ${ }^{1}$

Mugabe, speaking to a crowd of supporters that had gathered outside his presidential office on August 18, accused the congressmen for selling out for gay and lesbian votes, adding:

Let the Americans keep their sodomy, bestiality, stupid and foolish ways to themselves, out of Zimbabwe... Let them be gay in the US, Europe and elsewhere... They shall be sad people here. ${ }^{2}$

Mugabe told the crowd:

Homosexuality is prevalent in jails where there are mad people and criminals. But outside, we shall never accept it. ${ }^{3}$

Homosexuality in jails is a theme that recurs in the Zimbabwean debate. An explanation for this is offered by "Evelyn", in a report from Harare by a journalist from the Mail \& Guardian:

She suspects that Mugabe himself, when he underwent a 12-year prison sentence under Ian Smith, may have been sexually abused. It happens all the time in our prisons....

...It is because of the absence of any dialogue on the issue, Evelyn believes, that many Zimbabweans associate homosexuality with sexual abuse. ${ }^{4}$

President Mugabe continued to use the gay issue as a rallying point for the presidential elections in

1 Quoted in the Financial Gazette (Harare), reproduced by IPS Africa Aug. $18,1995$.

2 Associated Press and Reuters news service, as broadcast on "This Way Out", program \# 386, distributed Aug. 21, 1995.

3 Quoted in IPS Africa, Aug. 18, 1995.

4 Bart Luirink, "Zimbabwe's gays live in fear of future", Mail \& Guardian, Sept. 23-28, 1995.
March, 1996. At an interdenominational conference at the end of February, this year, organised by the Zimbabwe Assemblies of God Africa, Mugabe claimed that homosexuality and lesbianism were threatening to pervade the nation. He exhorted the church to help fight this danger. He claimed that he had received confidential messages from some presidents who said they also did not believe in homosexuality and lesbianism but would not dare say so publicly for fear of losing votes. ${ }^{5}$

The Zimbabwean press repeatedly returned to the issue of threats to "traditional values". The economic and social ills of society have receded into the background while "immorality", defined in sexual terms, has become a major theme.

\section{The parliamentary debate}

Mugabe received support for his stand from several of the ZANU-PF members of parliament. A few basic themes recurred in these debates.

To many speakers the question was seen not as one of individual rights but as a threat to society and culture seen as a body. Homosexuality was brandished as an alien import of sick habits, as unnatural, against the will of God and the need of reproduction, and many members joined Mugabe in advocating a campaign against homosexuals. A few excerpts from the debate will exemplify the tone and emphases of this argument.

Mrs. Tungamirai spoke for condemnation of homosexuality throughout the school, from grade 1 :

We should not ignore things as we were doing in the past. The reason why it has crept in[to] our society is because we have not been transparent about this issue. The problem with us is that, we think anything to do with sex must be hidden subject. It is not something to be debated in families. ---Since AIDS is being taught to our children,

${ }^{5}$ The Herald (Harare), Feb. 29, 1996 
we must also incorporate such issues. We must also convince them as to why this is wrong and why it is not part of our culture. It might be culture in the western world but not our culture here. We would like to be proud of our identity as Zimbabweans. ${ }^{1}$

Mr. Chigwedere's elaboration of what homosexuality is reads like a synonym list of moral condemnations:

I looked up a number of authorities and the sum total of all these definitions is this one. These homosexuals are people given to social pleasures. This is one definition. The second definition says these are people indulging in inordinate pleasure. The third definition describes them as licentious and this means morally rotten and promiscuous. The fourth definition describes them as lecherous, this means lewd, unchaste, base and given to debauchery. In the vernacular this means imbwa. ${ }^{2}$

To this speaker homosexuality was, above all, a threat to the society as an organism:

What is at issue in cultural terms is a conflict of interest between the whole body, which is the Zimbabwean community and part of that body represented by individuals or groups of individuals. --- The whole body is far more important than any single dispensable part. When your finger starts festering and becomes a danger to the body you cut it off. ---The homosexuals are the festering finger. ${ }^{3}$

Chief Makoni, who advocated whipping homosexual men, argued for isolating homosexuals both from society and from each other:

To meet as a man and a woman, there is a purpose of producing children but if a man and man meet, what will they produce? We have found very deterrent punishment in our society and punishments which used to stop the evil was to send culprits to places where they cannot do it anymore, but

\footnotetext{
${ }^{1}$ Mrs Tungamirai (Pamela-Mabvuku), Zimbabwe parliamentary debate, sept. 28, 1995.

${ }^{2} \mathrm{Mr}$. Chigwedere (Anias-Wedza), Zimbabwe parliamentary debate, sept. 28, 1995.

${ }^{3}$ Ibid. (Same as above).
}

today if you send them to prison, they enjoy more. Therefore, I think isolation of the guilty creating some form of punishment will help. ${ }^{4}$

In a somewhat contradictory way he urged that there should be no public debate on 'homosexualism', as it already had made children want to experiment. He also lashed out against donors raising the issue:

Through you Madam Speaker, let me shout to Zimbabwe as a whole that we do not talk about this rubbish in public. Let me shout to Zimbabwe that we should really point fingers to it as wrong, as sin and a devil's idea. Whether it comes from donors, let them know that we do not accept money to bribe us in order for us to indulge in wrong things. Let me speak to the whole world that we are Zimbabweans and we have a custom of our own. We know what is marriage and its purpose. ${ }^{5}$

Chief Mangwende was worried about what would happen to reproduction, especially with the existence of lesbians:

I would like to look also at the other side of the matter, where women are resorting to lesbianism. We should look at this case and see what pleasures women get in marrying each other and what pleasures men get in engaging in homosexuality. We have read in the Bible, where God said I create you so that you may multiply on this earth. How then are we going to multiply if we do not do it the right way? Are we going to produce any children if we promote lesbianism?

Finally, and implying an identification between the biology of human sexuality and that of other animals, Chief Mangwende announced:

We can see that animals are behaving in a better way. Cows know that they have to go to bulls only and the bulls know that they have to go to the cows. ${ }^{6}$

\footnotetext{
4 Chief Makoni, Zimbabwe parliamentary debate, Nov. 8, 1995.

5 Ibid.

${ }^{6}$ Chief Mangwende, Zimbabwe

parliamentary debate, Nov. 8, 1995.
} 


\section{The aftermath}

For the small homosexual community in Zimbabwe, and for the much larger group enjoying at one time or another same-sex intimacy without thinking of themselves in terms of a homosexual identity, there was fear that President Mugabe's speeches would inspire violence against them. A local journalist told a New York Times correspondent that:

Gay bashing goes on only at the highest political level. There's a good deal of tolerance on the ground. ${ }^{1}$

But with the mustering of support from the ruling party's Women's League there was a risk that they would repeat their methods from the electoral campaigns in 1985 and 1990, when they had broken into the homes of people supporting the opposition, beaten them and thrown their belongings into the street. ${ }^{2}$ If the Youth League, too, was mobilised there could be a witchhunt.

Although not reported in the Zimbabwean press, intimidation has occurred. GALZ members who had come to London reported on an incident where a black 24-year old gay man was arrested twice in one day after reading a poem at a convention on prejudice in August 1995. His picture was published in one of the Zimbabwean newspapers, and his college was informed that he was gay. Later the house which he shared with this mother was burnt to the ground. 3

The atmosphere of intimidation makes it difficult to know whether other similar incidents have occurred. It was reported that the GALZ organisation has been weakened and has entered a period of crisis following the book fair. One member

\footnotetext{
1 Donald McNeil, "For Gay Zimbabweans, a Difficult Political Climate", The New York Times, Sept.19, 1995.

2 Same source.

${ }^{3}$ Gay Times (London), Oct. 1995
}

says that the white members were scared to death of politics, whereas some black members "were a lot more combative". ${ }^{4}$

The persecution and arrests of homosexuals has almost exclusively been directed against men, but social prejudice against lesbians keeps them silent and out of the public eye. A member of GALz tells the story of a 24 year old lesbian woman from Gokwe, whose parents locked her up with a man when they found out that she was gay. The man raped her day after day until she got pregnant. She had an abortion, fled from her parents, but was taken home by the police, locked up and beaten. The man was again brought in, she was raped repeatedly and got pregnant again. She miscarried at seven months and fled her parents again. ${ }^{5}$

\section{Human rights and gay discrimination}

The GALZ incident dominated the debate on human rights at the 1995 book fair. One commentator who tried to put this into perspective was Henning Melber, director of the Namibian Economic Research Policy Unit (NEPRU) in Windhoek. In an extensive article, titled "Who Qualifies for Human rights?", in The Namibian, Melber argued:

Certainly, homosexuality is part and parcel of human rights concerns. But it is neither the only nor the most burning aspect of human rights and their violations. As a result, however, it became almost the exclusive subject of concern and debate during the Book Fair. Missing people, repressive laws, students beaten up on campus by police, restriction of the press and many more burning issues for those concerned with human rights, were

\footnotetext{
4 Bart Luirink, "Zimbabwe's gays live in fear of future", Mail \& Guardian, sept. 23-28, 1995.

${ }^{5}$ Story retold by Bev Clark in Unspoken Rules, published by the International Gay and Lesbian Human Rights Commission, related in Diva Magazine, Oct./ Nov. 1995.
} 
almost ignored. The dominant discourse centred around the debate on sexuality.

If it had not been such an emotionally loaded subject, one might well have suspected that the whole affair was deliberately initiated to sweep any other issue under the carpet. In this sense, the GALZ served as the useful scapegoat. This surely was not a carefully planned effect, but a (maybe desired) consequence of what happened. As if the human rights issues at stake should be limited to sexual practices alone.

Yet, as the weekly comment in Harare's Sunday Mail [August 6] maintained: "An ordinary Zimbabwean would conclude that the issue of lesbianism and homosexuality is definitely not a burning issue at all in this country or within the region for that matter". Because of this, the exclusion of GALZ would certainly not have been necessary, since the GALZ stand by all means would not have posed any meaningful threat to public morality. Yet, as the comment argued further: "Against the background of a belt of grinding poverty for the black people, ... the issue of whether or not love affairs should be conducted between couples of the same sex is hardly a matter to be highlighted as a human rights issue". But the non-issue was made the overriding subject neither by the GALZ, nor originally by the ZIBF organisers, but by the government. Because of its intervention, the GALZ' stand became the most popular meeting point-in spite of the fact that no publications were displayed.

... The Zimbabwe Book Fair emphasises its international character. But Internationalism is by definition active involvement and even interference into each other's affairs. Eye witnessing the exclusion of already marginalised minorities because of their private sexual preferences (and none of the gays and lesbians of Zimbabwe have threatened to demonstrate sexual practices in public shows), while the guiding theme of the Fair is human rights, causes at least uncomfortable feelings-to put it mildly. If the expression of such concerns is labelled and classified as hostile towards the host country, we have started to bury internationalism at a time when we need it more urgently than ever before. I therefore wish to conclude with the hope that attending the book fair next time, does not imply the exclusion of a neighbourhood of discriminated sections of society, who ought to have a legitimate right to participate in the freedom of speech. ${ }^{1}$

The South African Report saw Mugabe's attacks on gays "a symptom of his growing sensitivity to criticism" :

It suggests a warning to the media and others critical of the government that he is fast losing patience and will crack down on them. One could read in it a warning that freedom of expression cannot be taken too far.

... The message is reinforced by the prosecution of the Gazette under a rarely invoked "colonial" law. Though the paper showed incompetence in handling the Mugabe story, the charges were excessive and were seen as retribution for the paper's exposures of government maladministration, corruption and abuse of authority. ${ }^{2}$

The "incompetent handling" of the Mugabe story included a provocative use of irony. When Mugabe had called Zim-Rights, the human rights organisation in Zimbabwe, an organisation of "Zimlooters" the Financial Gazette retorted that such remarks were inappropriate coming from the chairman of "Robbers and Muggers (Rob \& Mug)". In February 1996 the owners of the Financial Gazette, Modus House, bowed to government pressure and sacked its chief editor Trevor Ncube and several other members of the staff.

\section{International protests}

The continued campaign against homosexuals in Zimbabwe was followed by international protests.

When Mugabe repeated his anti-gay stand at the World Bank-sponsored

\footnotetext{
${ }^{1}$ Henning Melber, "Who qualifies for human rights?", The Namibian, Aug. 11, 1995 also in the Southern African Political and Economic Weekly, SAPEM (Harare), Aug. 1995 as "Gays and lesbians in Zimbabwe".

2 The SA Report (Johannesburg), Aug. 18,1995
} 
Global Coalition on Africa meeting in Maastricht at the end of November 1995 Dutch Foreign Minister Hans van Mierlo told the Dutch parliament that Mugabe's statements contradicted the United Nations Convenant on Civil and Political Rights to which Zimbabwe was signatory. ${ }^{1}$

Before the Commonwealth heads of state met in New Zealand in November 1995 thirty-seven members of parliament wrote a message to president Mugabe appealing to him to see that he was persecuting a defenceless minority, and said:

We are sure that, as a black African who grew to adulthood in a whitedominated Rhodesia, you understand that discrimination is usually based on ignorance. ${ }^{2}$

In the Swedish parliament the Liberal Party MP Barbro Westerholm raised the issue first in October, 1995 and asked what the Swedish government does to show that it does not accept the encroachments against human rights described by her in the following terms:

Zimbabwe's president Robert Mugabe is leading a hate campaign against the homosexuals in the country. Prejudices against homosexuals have been elevated to a national campaign. There are proposals to put homosexuals in quarantine. Another proposal is to include condemnation of homosexuality in the curriculum. The campaign has meant serious encroachment on human rights and has been taken up, among others, by Amnesty International. ${ }^{3}$

Westerholm repeated her question on March 29, 19964 and the Swedish Foreign Minister, Lena Hjelm-Wallén replied:

The Swedish government views with great concern the verbal attacks on homosexuals in Zimbabwe. Our stand is

1 The Financial Gazette, Dec. 14, 1995.

2 Letter by Chris Carter a.o. , Oct.

1995.

3 Riksdagen, fråga till statsråd, Nr. 1995/96:64 (Swedish parliament, question to the Minister)

4 Riksdagen, fråga till statsråd, Nr. $1995 / 96: 362$. that discrimination and punishment of persons on account of their sexual orientation is entirely unacceptable. In a democratic society it is selfevident that people should be allowed to be themselves and in different ways express their orientation as long as it does not mean injure others. The question of the homosexuals' rights in Zimbabwe is thus closely linked to the general respect for human rights and freedom in the country. The situation for the homosexuals is taken up with Zimbabwe in connection with other deficiencies in this area. ${ }^{5}$

The question after the crisis of the book fair in 1995 was whether it signalled a new chapter for and understanding of human rights, and the acceptance of homosexuals, or whether it was a symptom of the erosion of universal human rights in the name of indigenous values, as interpreted by those in power. In 1996 that question was not yet answered. The struggle continued with yet another book fair drama.

${ }^{5}$ Utrikesdepartementet, utrikesministern, (The Swedish Foreign Ministry; the Foreign Minister), April $10,1995$. 


\section{Zimbabwe-The Second Book Fair Drama 1996}

At first it all looked like a repetition, when the Zimbabwean government announced, just a week before the opening of the 1996 Zimbabwe International Book Fair, that the Gays and Lesbians of Zimbabwe (GALZ) was again prohibited from exhibiting. ${ }^{1}$ on top of it all this announcement was made by the same government spokesman as last year, the Director of Information Bornwell Chakaodza.

But it was not all the same. There were a number of significant differences: the book fair organisers and GALZ were not caught unaware and wanted to defend their rights, the government was divided, and the threat was not this time the expressed rage of the president but threats of violence. ${ }^{2}$

\section{"No government pressure will be submitted to"}

The GALZ issue had caught the book fair organisers by surprise in 1995. The debate had shaken the trustees and had forced them to think hard about its implications. In anticipation of the next book fair the trustees took a much more principled stand in a statement strangely labelled "private and confidential", although sent to a number of foreign funders:

The ZIBF Trust Executive committee
would like to reiterate its
unequivocal commitment to freedom of
expression and the dissemination of
information. The committee has
implemented a policy that all
applications to participate at ZIBF

${ }^{1}$ The Herald, July 24, 1996; Panafrican News Agency 23 July 1996.

${ }^{2}$ This section is based on quoted written sources, and on interviews and observations by Mai Palmberg, who participated in the 1996 book fair representing the Nordic Africa Institute.

\begin{abstract}
will be considered purely on legal grounds. ...No government pressure will be submitted to by the Trust. If the participation of any organisation/individual is questioned/objected to, the matter will be dealt with by the ZIBF's lawyers in a court of law. ${ }^{3}$
\end{abstract}

In October the book fair trust reiterated its "determination to maintain and develop the ZIBF as the premier pan-African book trade event and to do so in accordance with international standards and requirements." The statement continued:

In the wake of the Zimbabwe
government's directive banning Gays
and Lesbians of Zimbabwe (GALZ) from
participation in the 1995 Zimbabwe
International Book Fair, the Trust
has reiterated its unequivocal
commitment to freedom of expression
and the fullest dissemination of
information. The Trust is confident
that the Constitution of Zimbabwe
provides ample protection for freedom
of expression. It will uphold the
terms of the Constitution, if
necessary by appeal to a court of
law. All applications to participate
in the zIBF will be considered purely
on legal grounds and without any
submission to government pressure.

GALZ, too, were prepared themselves for future confrontations with the government. They were naturally encouraged by the vigorous international protests, and by the tougher stand of the book fair management, although sceptical of their will to really stand up against the government. GALZ had overcome the crisis after the 1995 book fair, and had received grants from Dutch and Canadian sources. They had put together a small book, Sahwira, with

\footnotetext{
${ }^{3}$ Statement from ZIBF Trust sept. 14, 1995, circulated to SIDA, APNET, SABDET, NORAD, HIVOS, NOVIB, PASA, and the resigned trustees.

4 ZIBF press release Oct. 6, 1995.
} 
a unique collection of life-stories on being homosexual in Zimbabwe. They were in contact with lawyers regarding their rights. It was with some confidence that they had submitted an application for a double stand at the book fair just before the dead-line. As promised they were accepted.

\section{A divided government}

As soon as news was out in Harare about GAL' participation in the 1996 book fair a rather nasty mass media campaign started with the familiar themes we saw in the previous chapter. And yet when interviewed by the press the Minister of information, post and telecommunication, Joyce Mujuru, said the government could not intervene if GALZ participated, whatever views the government held on the issue. ${ }^{1}$

Even so, after Chakaodza's statement the media made people believe that there was only one government line. Indeed, Minister Mujuru was quoted during the book fair week blasting homosexuality as foreign imposition of values, in a speech held at a seminar for journalists. ${ }^{2}$ But this part of the speech had (according to a reliable source) been added by the Minister's subordinate, Bornwell Chakaodza, who had also described Mujuru's earlier statements on non-interference as pure phantasies.

President Mugabe remained totally silent in 1996 about the GALZ issue. It was hard to believe that he had changed his mind, but apparently

\footnotetext{
1 The Herald, July 22, 1996, p.1.

2 The Herald, July 29, 1996. Mujuru was quoted as saying that "The heart of the matter is that the cultural values of the majority do not accept homosexuality", and that homosexuals by going public are "disturbing the existing social equlibrium and violating the rights of the majority", and that Zimbabwe had a right to protect and promote the cultural values that constituted the Zimbabwean Nation."
}

there must have been second thoughts on the wisdom of his previous line in public outbursts. When the book fair started, President Mugabe was on a visit to Malaysia, but he returned three days before it ended. After the fair, at the Heroes' Day, where the year before he had made his famous "worse than dogs and pigs" speech homosexuals were not mentioned.

Perhaps the presidential silence was only a temporary tactical retreat to avoid unfavourable comments on his own morality in Zimbabwe. Preparations were under way for President Mugabe's wedding in August to his former secretary, with whom he had children, not previously recognized as his.

\section{Threats of physical violence}

There was a risk that verbal abuse against GALZ could escalate into physical threats. A newly founded Christian Communication Association of Zimbabwe, and an "affirmative action" student organisation called Sangano Munhumutapa had threatened havoc and violence if GALZ are allowed. Its leader, Lawrence Chakeredza, had said:

We are ready to raze down the stands
and go to jail. Our actions will be
for a noble cause. We want to protect
the values of our culture. The
essence of the fair should be
exhibiting what the country has
achieved and can offer in literal
arts, and
homosexuality.

These threats were publicized by the government controlled media and were thought to serve the interests of the government-led campaign by giving the impression that people of Zimbabwe abhorred the foreign imposition of decadent values, which was how homosexuality was portrayed officially. Significantly, when GALZ asked for police protection this was refused. The risk of officially inspired and/or condoned mob

3 The Herald, July 23, 1996, p.7. 
violence was taken seriously by those concerned. The threat of violence cast a shadow over the whole 1996 book fair.

Let us follow the book fair drama 1996 day by day, and then discuss the conclusions that can be drawn from this.

\section{Sunday, July 21}

The Director of ZIBF, Trish Mbanga, was questioned in a national Zimbabwe Broadcasting Corporation TV programme, "Insight" about the decision to allow GALZ to exhibit at the book fair. She said that the book fair wanted to exercise democracy, and suggested that those who did not like to see GALZ there could just ignore them. She also said that she did not agree with all views and forms of behaviour represented at the book fair, for example, with the way Moslem men treat their women, but would not prohibit different voices from being heard.

\section{Tuesday, July 23}

The director of information, Mr. Bornwell Chakaodza announced that a banning order would bar GALZ from renting a stand at the Zimbabwe International Book Fair and also at all future book fairs. ${ }^{1}$ Announcing the banning order Bornwell Chakaodza said:

Gays and lesbians have, like anyone else, a right to live, but they have absolutely no right to publicly display literature and material at a public and cultural event where hundreds of children visit to fulfil one of ZIBF's commitments, which is 'to uphold the right of the people of Africa' to have full access to books which are culturally and materially relevant to their reading needs.

This represented a nuance shift from 1995. Now the homosexuals have "a right to live" but not to show that

${ }^{1}$ The Herald, July 24, 1996. they exist, nor to speak as homosexuals.

\section{Wednesday, July 24}

Since no banning order actually appeared in writing the book fair trust took no decision on GALZ, but proceeded with preparations as usual. for the book fair itself and the conferences and workshops held in conjunction with it.

\section{Thursday, July 25}

GALZ issued a strong statement ${ }^{2}$ to the effect that they were legally participating in the book fair, and had appealed to police protection against harassment.

The Zimbabwe Human Rights executive director David Chimhini was quoted in the Herald as saying that there should be a national debate on homosexuality to determine the needs of society. He also said that "The banning of Galz from exhibiting at the book fair is an overreaction by the Government which is not in harmony with the current international thinking on the issue. Yes, Zimbabwe is a sovereign country and we should never give up our hard-won independence, but our practices must be seen to be just, by our own laws." ${ }^{3}$

The government-sponsored The Herald carried a strange interview with professor George Kahari, one of the board members of the Zimbabwe Book Fair Trust, and also director of the National Gallery of Zimbabwe (on whose ground the book fair is held). He said that GALZ should stay out and if they did not, law should take its course. He was also quoted as concurring with the view that homosexuality is "against our culture". ${ }^{4}$

\footnotetext{
2 The Independent, July 26, 1996, also distributed on Internet.

3 The Herald, July 25, 1996.

4 The Herald, July 25, 1996.
} 


\section{Friday, July 26}

In a paid advertisement in the Herald the executive committee of the ZIBF Trust expressed their full support for the director, Trish Mbanga, who was said to carry out the directives and line of the Trust.

\section{Saturday, July 27}

In an article entitled "Stand Against GALZ Praised", the Herald quoted a ZANU spokesman who said that the ZANU(PF) Harare Province had the power to rouse all its members to demonstrate against GALZ. ${ }^{1}$

On the last day of the Indaba (conference) on national book policies, one speaker brought up the GALZ issue, which hitherto had been mentioned only in informal discussions off the record. The General Secretary of the South African Writers Union (COSAW), Raks Seakhoa, opened his remarks by saying that it would be unfortunate if the book fair was burnt to ashes. He added that the book fair could not colse without condemnation of the encroachment of human rights. Later in the day the chairperson of the ZIBF Trust, Elliott Mugamu, explained the situation and reiterated the support of the trust for freedom of expression, and for the director's work.

The Indaba ended with resolutions on the themes it had discussed, such as the importance of indigenous languages in book production. There was a separate resolution emphasising the importance of freedom of expression for the book fair, but with no explicit mention of the GALZ issue.

News reached us inside the hall in the Monomotapa Hotel where the Indaba was held that there were aggressive demonstrators outside the book fair gate, close to the office

1 The Herald, July 27, 1996. where the director Trish Mbanga was working. A dozen participants left to show Trish Mbanga our moral support. A group of about 30 young men and women claiming to be "Artists against AIDS" were singing and drumming outside the gate where they had put up some non-artistic posters against GALZ and against Trish Mbanga. Unfortunately one of the book fair participants, Peter Ripken from West Germany, tore down two of their posters (for which he was dubbed "Peter the Ripper"). It was hardly a wise thing to do when we were defending freedom of expression. Police came, but made no arrests. The demonstration all had the appearance of a "rent-a-crowd", with a few aggressive ones and the rest non-violent followers. In the end this was the only organised demonstration against GALZ.

\section{Sunday, July 28}

GALZ held an extraordinary meeting to discuss what to do. They reaffirmed their position to enter the book fair but also stated that they were totally non-violent in their approach and appealed to those who had threatened violence to "desist from such irresponsible behaviour". The statement also said:

The banning of GALZ has no basis in law and as members of civil society, GALZ will not be bullied by government into withdrawing. It is a disgrace that politicians should put themselves into the position of determining moral codes of private individuals.

Regarding the cultural issue that homosexuality is un-African GALZ states that in any democratic state where every individual is guaranteed the inalienable right to freedom of expression, gays and lesbians must also be permitted to express themselves through their own gay and lesbian culture. Cultures are the belief systems and behaviour patterns of individuals; they are not the moral prescriptions of dictatorial bodies. Cultural diversity is to be encouraged and not to be curtailed by oppression and tyranny. 
The right to freedom of expression is guaranteed under the Zimbabwean constitution and yet we are faced with a government Ministry which seeks to curtail it-there is nothing more Orwellian than that! ---

Homosexuals exist within all strata of Zimbabwean society. It is inhuman to persist with this persecution of us. The plight of homosexual people in this country is harrowing and the government must take full responsibility for increasing the torment.

---The gay community is standing up not just for gay rights but for the holistic principle of freedom of speech which applies to all individuals and communities in this country. We are proud to be Zimbabwean and proud to be gay. ${ }^{1}$

In the Sunday Mail Justice Manyarara was quoted as being highly critical of the way that the journalists had treated the whole issue:

Justice Manyarara claimed homosexuality existed in traditional Zimbabwe. He said he had read this from an article published by a local magazine. "The story was killed by not being republished by anybody else-I have the clipping. This is self-censorship," he told participants who included journalists from Uganda, Tanzania, Kenya, Cameroon and South Africa.

Justice Manyarara said Zimbabwean journalists had not investigated the legality of the ban on GALZ. He said he personally knew that the ban was illegal. He challenged Zimbabweans to carry out a referendum on the matter.

No journalists had any knowledge on what was going to be exhibited, so how can you begin support the banning, he said.

\section{Monday, July 29}

A statement issued on Sunday by the Legal Resources Foundation was quoted in the press as criticising the ban on ground of international law:

Section 20 of the Constitution deals specifically with the protection of

\footnotetext{
${ }^{1}$ Statement from the Gays and Lesbians of Zimbabwe (GALZ) dated July 28, 1996.
}

freedom of expression which includes the right to receive and impart ideas and information without interference.---

Government has declared its adherence to constitutional rights and to the International Covenants to which Zimbabwe is a signatory and in which freedom of expression, assembly and association are pivotal. The dictatorial statement by the Director of Information that Galz may not exhibit either at this or any future Book Fair in this country, brings this into question. ${ }^{2}$

Significantly the Herald report concluded by saying: "Those supporting the participation of Galz at the Book Fair have been the human rights organisations and lawyers", by that is implied that it is only their petty sectarian interest that is concerned.

Early on Monday the ZIBF board of trustees declared that they would not ask Galz to leave since they were a legal organisation and therefore had the right to take part.

Later in the day, the chairman of the Board of Censors, H. Malaba, gave a "notice of prohibition" directed to the director of the Zimbabwe International Book Fair Trish Mbanga and to Gays and Lesbian Association of Zimbabwe stating that:

The Gays and Lesbians of Zimbabwe
(GALZ) is prohibited from
establishing or exhibiting at the
Zimbabwe International Book Fair to
be held at Harare from July 30 to
August 3, 1996. The order is based on
17(1) of the Censorship and
Entertainments Control Act CAP 10:04
and was taken by the board of censors
in consultation with the Secretary
for Home Affairs.

This order meant that both Trish Mbanga and Keith Goddard, acting administrator of GALZ could have been arrested if the order were contravened.

The ZIBF felt compelled to issue a statement saying that they had to comply with the laws of Zimbabwe.

\footnotetext{
2 The Herald, July, 29, 1996
} 
Despite their september 1995 statement (quoted above) that government questioning or objecting to the participation of any organisation/individual would be handled by ZIBF lawyers in a court of law, the trust at this point was not prepared to fight a legal battle.

\section{Tuesday, July 30}

GALZ challenged the government in court and questioned the validity of the order from the board of censors. It noted that the notice was not even written on official paper. In a statement it condemned the actions of what by mistake was called the Ministry of Homoe Affairs [sic].

The book fair was officially opened in the evening by John-Willy Rudolph, head of KOPINOR in Norway, an organisation to set up procedures for remuneration to authors of copying material illegally. At the end of his speech he referred to the GALZ issue, without mentioning the organisation by name. It is sad, he said, that one registered participant was excluded from participating, and added that he wanted to salute the balanced views expressed by Justice Manyarara (see above). Rudolph added that the Zimbabwe International Book Fair must be seen as an international event, with international high standards of freedom of expression. ${ }^{1}$

The Association of Namibian Publishers (ANP) issued a statement (not quoted in the press but circulated at the book fair), saying among other things:

We find no justification for the Government of Zimbabwe's intervention to once again prevent the Gays and Lesbians of Zimbabwe (GALZ) from participating in the Zimbabwe International Book Fair. We cannot see any violation of accepted international norms by the fact that literature by and on homosexuals is displayed at an international book fair. Gays and lesbians are as much part of a world wide, complex socio- cultural set-up as many other minority groups. We do not believe that they are violating anyone else's rights by their own orientation and way of living as long as they do not impose this upon others.

In a press statement Amnesty International condemned the banning order and said that it could be a prelude to further human rights violations against GALZ members and supporters.

\section{Wednesday, July 31}

The High Court declared invalid the government order prohibiting GALZ from putting up a stand and exhibiting material at the book fair. Judge-President Sandura said it was unreasonable for the censorship board to ban material it had not seen and that the censorship board could not prohibit pieces of wood and canvas from being erected in the shape of a stand at a public fair. The government attempted to lodge a counter-appeal against Judge Sandura's ruling, but this was dismissed by the High court. A government appeal was then lodged with the supreme court, which, however, did not handle the matter during the book fair.

The book fair trustees met before the court order was known, and decided after considerable discussion, that they would follow the law and allow GALZ to exhibit if the banning order was declared unlawful.

At the same time, the student representative council at the University of Zimbabwe was reported in government-sponsored the Herald to have condemned the book fair management for letting GALZ participate, and saying that if they did, they (the students) would definitely be there, and it should be known to the ZIBF management "that their uncultural behaviour may prove detrimental to the Book fair" and may see the gays and lesbians

\footnotetext{
${ }^{1}$ My notes.
} 
"face public genocide unceremoniously".

\section{Thursday, August 1}

Galz came to their book stand on Thursday morning, two hours after the Zimbabwe International Book Fair opened to the public (after two days for traders in the book business). Their stand had already been given to a late-comer, but since GALZ had paid they were given their rightful stand. GALZ did not, however, bring any material. When the GALZ spokesman Keith Goddard appeared in the stand, the press and a crowd of people assembled around the stand in such numbers that you could not see him. With Keith Goddard were some other members of GALZ, including at least two black gay activists.

\section{Friday, August 2}

On Friday GALZ were not at the book fair at all, since a number of hostile young men had assembled at their stand, and GALZ felt that there was not enough security to protect them or their visitors. Their double stand remained empty the whole day, with only two bouquets of flowers as a sign of support. GALZ explained their absence in a later statement:

On the second public day ... GALZ was forcibly prevented from taking up its position at the Fair because a violent mob, led by Public Prosecutor, Herbert Ushewokunze, descended on the GALZ stand. The public Prosecutor stated that he and his followers represented 'the People's Court' and that they "did not care about High court Rulings". This provided concrete evidence of a direct link between government and the violence against GALZ. ${ }^{2}$

When I passed GALZ stand there were some aggressive young men in the crowd, but most people seemed just curious. Somebody had written

\footnotetext{
1 The Herald July 31, 1996, p. 11.

2 Statement from the Gays and Lesbians of Zimbabwe (GALZ) dated Sept. 5, 1996.
}

"Pasi nengochani" on a small piece of paper and stuck it onto the flowers. I extracted a translation which was "Down with the homosexuals" (strangely enough Shona does have a word for what some deny exists!). Nobody dared admit they had written it, and nobody dared protest when I took the paper and walked away.

The Zimbabwe Independent, a weekly paper, appeared with good coverage of the GALZ issue. On the front page was a picture of three GALZ activists (one white man, two black women) in their stand, headlined "Under Siege".

\section{Saturday, August 3}

On the last and most popular public day of the fair GALZ came with a well-decorated stand. At their own demand their stand has been moved away from the book fair proper to the so called Mayor Garden, which is also inside the gates, but a separate ground used for big meetings and with two food places. GALZ wanted to secure the possibility of escaping through a back gate if the situation became nasty.

Even before the fair opened, while GALZ were decorating their stand with two paper figures supposed to be a pair of women and a pair of men, some reading material, and clippings from the Zimbabwean press, there was a crowd of people listening and putting questions to Keith Goddard, the spokesman for GALZ at the fair. Keith Goddard is a small and gentle man, whose profession-ironically-is to promote traditional Zimbabwean culture. The atmosphere was friendly, and some of the guards also got into the crowd to listen. There were also some Zimbabwean journalists, who wanted to hear the other side of the story, and were concerned about the safety of the GALZ members.

When I saw the stand again at noon, or rather the crowd surrounding GALZ, there were some 
fairly aggressive young men around the stand, even some standing on their table. The members of GALZ patiently answered questions and explained who they are and why. Next time I passed their site, however, in the late afternoon, they were gone, and so was the stand.

Rumours spread that there had been some sort of attack, a rumour seized upon by sensation-hungry journalists. This is GAL' own report:

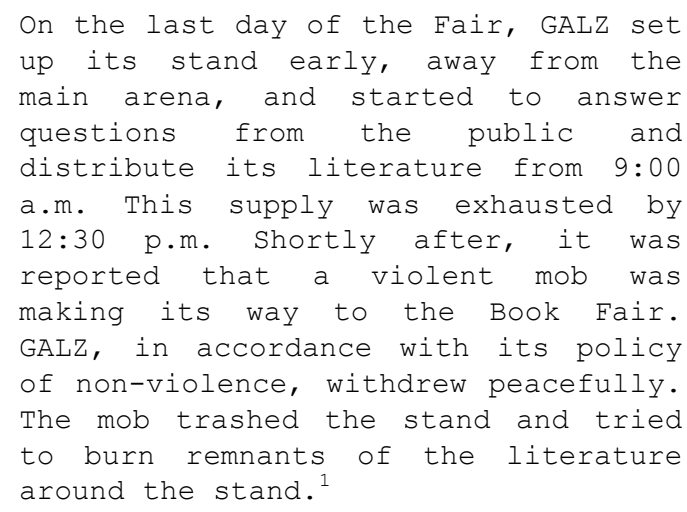

\section{Civil society versus government}

The 1996 book fair drama was to a much larger extent than the previous one a battle between civil society and the government. The independent judgment of the High Court, the much stronger statements this year of the three human rights organisations, the relatively tougher stand by the Zimbabwe International Book Fair leadership and the persistence of GALZ itself, put the issues of freedom of expression and human rights squarely on the agenda. GALZ and with it civil society won the battle and earned a lot of respect for its courage and prudence.

The role of Zimbabwean mass media is open to question. Despite the fact that they gave very little coverage of the book fair other than writing about GALZ their reports were often misleading, and often lent themselves to an incitement to violence. There were exceptions, but not in the leading mass media,

\footnotetext{
${ }^{1}$ Loc.cit.
}

notably The Independent and some journalists who wanted to hear "both sides".

Despite the fact that there in the end was very little violence, the threats of violence loomed large. Threats of violence is part of violence and intimidation. The fact that there was no statement against violence from any Zimbabwean leader was a sign of lack of moral leadership.

The presidential gay-bashing has also helped to erode the respect for legal rights. One day I had a heated discussion later with a student who defended the right of violence and claimed that the courts and lawyers could be ignored, since "they will permit anything. This is not a question of law" he added, "it is a question of culture".

\section{Scapegoats}

One can ask-as some students did-why the government uses riot police against students and arrest some of their leaders, while they have not arrested Galz leaders, nor did they ban Galz as an organisation. My interpretation of the situation is that, however happily the government would live without homosexuals, it knows that after the furore follwing the 1995 book fair any move to ban GALZ would be unwise. In any case, GALZ is a small group and poses no real threat either to government or to the country. Students, on the other hand, represent a large constituency with which government has had difficult-and sometimes very difficult-relations; government sees it as being vital to manage these relations in a way that protects its own interests (and perhaps-though more doubtfully-the interests of the country) and will act with force against students when it deems necessary.

The GALZ issue at the book fair is a matter of prestige for the government and president of the country, and verbal gay-bashing has 
provided a mechanism for whipping up political support for the ruling party at a time when common people are suffering from rising costs and lesser services, low prices for their crops and growing and glaring disparities between the few rich and the many poor.

My own impression is that this strategy hass not worked. Homophobia is NOT the general feeling of the people of Zimbabwe. I met a lot of ignorance but also curiosity. The GALZ issue has opened the eyes of many Zimbabweans to the absurdity of making a small defenceless minority like the GALZ the scapegoat of people's frustrations.

The government attitude does hamper information, but at the same time the 1996 book fair drama served as effective advertising for GALZ, and various cultural initiatives, such as community theatre plays, are planned which will treat homosexuality as a theme.

But whereas people in the capital of Harare are more open-minded (except for small groups of homophobic men), the people in the countryside are less informed and dependent on the rhetoric of their leaders. Another factor is that an increasingly authoritarian character of the ZANU-PF rule has left people with relatively little civil courage.

It is not insignificant that the gay-bashers are young men. As in many places in Africa, changing times hits the men's traditional roles particularly severely.

The black women in GALZ were more at risk for violence than others. After the book fair one of the activists was seriously threatened and intimidated by a local ZANU-PF Youth League in her hometown.

\section{Continued international watch}

The international community will have reasons to continue to watch developments on human rights and homosexuality in Zimbabwe. In response to an international campaign during and after the book fair 1996 several donor governments, among them Canada and Holland, said they continuously keep in touch with developments.

Some voices were raised in favour of a boycott of the book fair. This would be a blow to civil society in Zimbabwe, and to thousands of people who gather to the fair grounds in a very real book hunger. But it would probably not move the government much. The lessons to be learnt from other boycotts, notably that of apartheid South Africa, was that the cultural boycott missed the target, whereas economic pressure could yield results.

The issue of homosexuality and human rights in Zimbabwe will continue to gain international attention. It is already a bone of contention for the World Council of Churches anniversary conference to be held in Harare in 1998. The churches are wavering while the government of Zimbabwe is trying to prevent the issue from being on the agenda, and particularly any criticism being voiced against it. 


\section{African Views on Homosexuality}

\begin{abstract}
Mugabe is not the only African homosexuals. Echoing a widely held view that homosexuality is a white importation to Africa, Kenyan president Daniel arap Moi has claimed that "words like lesbianism and homosexuality do not exist in African languages". ${ }^{1}$ Kenya's principal immigration officer, Frank Kwinga, agrees, arguing that "homosexuality is... morally unacceptable in our country." ${ }^{2}$

Until recently in Africa, public comments on homosexuality have been fairly infrequent. Former Tanzanian president Julius Nyerere, a politician who is admired for his progressive views on a range of issues, argued in 1974 that homosexuality is a phenomenon alien to Africa and that in Africa, therefore, there are no grounds for homosexuals and lesbians to be defended against discrimination (Nyerere's comments were made in the course of an interview with Hubert Fichte, but were omitted in the published version). ${ }^{3}$ Nyerere's comment might be seen as illinformed rather than as a crude display of prejudice as the issue of homosexuality at the time was not debated as openly as now.

There exists a culture of silence. within which questions of sexuality-of any kind-are not often debated openly and frankly. In Africa this is partly the result of a vacuum created when old mores are no longer upheld, especially in
\end{abstract}

\footnotetext{
${ }^{1}$ Mail \& Guardian, (Johannesburg) Sept. 29, 1995, p. 3 .

2 The Guardian (London) Nov. 3, 1993, p. 12 .

${ }^{3}$ The abridged interview appeared in the Frankfurter Rundschau, June 10, 1974, p. 14. The material cited is from a complete transcript of the interview in the possession of the authors.
}

communities going through urbanisation. In the old days, sex education was transmitted to the young during initiation rituals, but where traditions are breaking down this no longer works. The formal education in modern schools have not filled this vacuum, especially since the modern school system was introduced by missions societies, which carefully omitted giving any sex education. These schools instead transmitted the ideology that sex within marriage was the only natural and permitted sexual activity, and that reproduction was its purpose.

What public commentary there has been on homosexuality has, until recently, been almost uniformly hostile. Amongst literary works by black African writers there are only a few that treat homosexuality with sympathetic understanding. There is a Tanzanian short story by D.N. Malinwa on a homosexual relationship between two black working class men $^{4}$, and the work of the Cameroonian novelist Calixthe Beyala. But such texts are few and far between. In the great majority of novels and stories by black Africans that mention the subject, homosexual relations are targeted as being unnatural, abusive and exploitative. ${ }^{5}$

In the press generally, commentary has largely been based on a couple of basic contentions.

\footnotetext{
${ }^{4}$ D.N. Malinwa, "Everything Under the Sun" in O.R. Dathorne and Willfried Feuser, eds., Africa in Prose, (Penguin, Hamondsworth 1969), pp. 263-270.

${ }^{5}$ For accounts of this literature, see Chris Dunton, "'Wheyting is dat?': The Treatment of Homosexuality in African Literature", Research in African Literatures, Vol. 20, No. 3, Fall 1989, pp. 422-448; Chris Dunton, "Gay and Lesbian Sexuality", in the oxford Companion to African Literature (forthcoming).
} 
First, that homosexuality is an offence that can readily be conflated with other offences, such as bestiality, child abuse and the marketing of pornography. ${ }^{1}$ Second, that-in the words of a 1987 Lagos publication-"homosexuality is still largely a Euro-American perversion which has not yet any foothold in Africa" ${ }^{2}$. Or, as one Nigerian popular novel put it, it is "grossly repulsive, un-African and most unlikely." ${ }^{3}$

A word that is often used in stigmatising homosexuality in Africa is "tradition"-the argument being that homosexual relations are incompatible with traditional African social practice. But there is such a thing as "the invention of tradition"-that is, the manufacture, or at least simplification, of ideas about traditional practice in order to serve the interests of particular groups, or to provide a politically convenient and sanitised reading of history and of the nature of specific communities. As a writer calling him/herself Umfana argues (in a letter to The Namibian following the Book Fair incident):

The opportunist turning tradition into a convenient supermarket for tools of power makes a mockery of it. Traditions contain moral principles, but that does not mean that we are allowed to shirk the obligations of moral discourse. ${ }^{4}$

The exclusive attribution of homosexuality to Western influence raises other questions, too. There is a false implication that homosexual relations are entirely accepted within western societies and western culture. The actual situation is different. Although some countries have outlawed

\footnotetext{
${ }^{1}$ See, for example, a letter in the Mail \& Guardian, Feb. 23, 1996.

2 Monthly Life, Vol. 4, No. 5, May 1987, p. 8 .

${ }^{3}$ Edia Apolo, Lagos Na Waa I Swear (Heritage Books, Lagos 1982), p. 44.

"Umfana, "On Tradition and Gay Rights", The Namibian, Oct. 13, 1995, p. 6.
}

discrimination of persons on grounds of their sexual orientation, there is a battle raging in almost all Western countries for and against acceptance of homosexuals and homosexuality. The arguments used in these debates are of the same type as those that we quote here from the debate in southern Africa. We would venture to suggest that these battles are not about traditions versus foreign and strange patterns of behaviour, but between humanism and authoritarianism, or, expressed differently, for or against a human rights culture.

\section{African homosexuals defend their rights}

Occasionally in the past the African press has debated homosexuality in a way that is relatively open. For example, an extensive article in the Sesotho-language paper shoeshoe not only admits that the practice of homosexual behaviour can be found amongst men in Lesotho, but gives space to these men to argue their own defence. One interviewee says:

We opened a club for ourselves at Moshoeshoe II (suburb of Maseru, capital of Lesotho). But people passed bad remarks about it until we closed it. What makes me wonder and fail to understand, is why these people must condemn us and why they should get involved. ${ }^{5}$

It is worth noting that this article appears in a newspaper published by Lesotho's Department of Information.

The letters' columns of newspapers have occasionally given space to African men who love men, and women who love women, to defend themselves. Some such letters are quoted in the chapter on Botswana below. Another appeared in the Lesotho paper The Mirror, which also published a photograph of the author.

I am a 22 years old man Stadium area in Maseru. I have got a straight

\footnotetext{
5 "Banna ba 'maotoana' ba itseka", Shoeshoe (Maseru), Oct. 14, 1993.
} 
looking man friend, who was not really getting satisfactions from his heterosexual practice until he found where his satisfaction is-which was the gay sexual way of life.... It did not take him long to realise that being gay is not the end of the world and that he could live more happier than ever before. He has tried with other man friends and found out that his problems are solved. We know that people do not accept our way but is there anything wrong in it? ${ }^{1}$

What has been visible in the southern African press since the Zimbabwe Book Fair incident in 1995 is a growing willingness to give space to the discussion of homosexuality. Whether this will prove to be only a temporary opening-up of the debate remains to be seen. Clearly, though, President Mugabe's intervention and its aftermath have brought the discussion of homosexuality closer into the mainstream. Much of this debate remains homophobic, with the inherent paradox that the expression of homophobia by African politicians and others seem often to amount to saying that "homosexuality doesn't exist in Africa -but don't do it anyway because it is rotten".

More important is the fact that the voices of women who love women and of men who love men are being heard in a way that has rarely happened before. Here are the voices of men and women who are responding assertively to the denial of their existence or the denial of their rights.

In the next section we move towards a discussion of human rights organisation amongst African gays and lesbians. First, however, we believe it is necessary to discuss questions relating to individual identity, that is, to the way individuals think about themselves and their behaviour, and the way they relate this to the nature and behaviour of other members of their community.

\footnotetext{
1 "Is it Sin to Be Gay", The Mirror (Maseru), Nov. 20, 1992, p. 8.
}

\section{Questions of identity}

Can we realistically talk about an African homosexual community? Do the individuals whose lives are discussed in the previous section form a community of African gays and lesbians? Do they think of themselves and talk of themselves as members of a homosexual community? Perhaps we should talk, less categorically, about men who love men and women who love women, a phrase that we deliberately introduced above. By this expression we want to include men and women who have a sexual preference for members of their own sex, and men and women who occasionally and voluntarily engage in same-sex sexual acts, but who nevertheless do not consider themselves members of a homosexual community.

It is important to face here questions of culture and the possibility that-without overgeneralising-people of different cultures may have different ideas about the way their sexual preferences and sexual behaviour contribute to their identity. The question to face is whether the idea of a gay and lesbian community is a Euro-centric phenomenon.

There exist published autobiographical accounts (that is, accounts of one's own life-story or life-style) written by black African gays and lesbians: or, more specifically, by black Africans who explicitly regard their sexual preference for and attraction to members of their own sex as something that significantly contributes to their identity, their sense of who they are. There are the letters to the press mentioned above, and those we cite from the debates in the wake of the book fair. Recent anthologies of writing on gay and lesbian lives in South Africa include pieces by black men and women, including work by black gay and lesbian rights' activists 
such as Simon Nkoli and Tanya Chan Sam. 1

These writings are appearing more frequently now than twenty, or even ten years ago. Yet it is clear that in South Africa (and probably in southern Africa generally) the majority of gays and lesbians who write on homosexuality are white.

Does this bring us back to the idea (common in the homophobic writing discussed above) that homosexual behaviour is virtually absent amongst black Africans? Or does it, rather, raise questions about identity and about discoursethat is, about the way different communities talk about certain things and the way they may or may not give specific names to particular kinds of behaviour?

There seems quite a lot of evidence to suggest that in black communities homosexual behaviour is recognised as a fact of life but rarely discussed. Accounts by black gays and lesbians in The Invisible Ghetto and Defiant Desire bear witness to this. The same seems to be true of black communities elsewhere-at least at certain points in history. Neil Miller writes of Harlem, New York, in the 1920s:

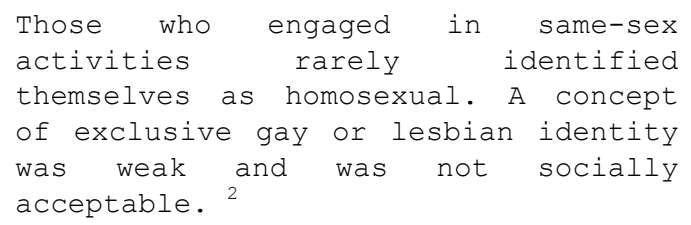

In the same book the novelist samuel Delaney quotes the black (Harlem Renaissance) writer Bruce Nugent as saying:

I just don't see why everyone has to be labelled. I just don't think words

\footnotetext{
1 See Matthew Krouse and Kim Berman, eds., The Invisible Ghetto (Johannesburg: COSAW 1993); Mark Gevisser and Edwin Cameron, eds., Defiant Desire (Braamfontein: Ravan Press, 1994).

${ }^{2}$ Neil Miller, Out of the Past: Gay and Lesbian History from 1869 to the Present (New York: Vintage, 1995), p. 150.
}

like homosexual-or gay-do anything for anybody. ${ }^{3}$

Nugent here refers to "words", that is, to categorising names that define group identity, like "gay" and "homosexual". When President Mugabe and others describe homosexuality as "un-African", a common response has been to cite the existence of words for homosexuals and homosexual behaviour in African languages. The Shona word "ngochani" is often cited." Other examples include the Sesotho word "maotoana" and the Hausa phrase "dan kashili". Yet perhaps the existence of these words is not all that helpful in establishing facts about homosexuality in Africa. What after all, are the origins of these words? How are they used-as neutral descriptions or as derogatory terms? How widely are they used and in what contexts? And what would it mean if these words did not exist-that black African women never had sex with other women, or men with men?

We should point out here that as we attempt to understand the history and experience of men who love men, and women who love women, the question of naming and the significance of historical and linguistic record seem fraught with problems. Both the importance of seeking scientific information and hard facts, and the difficulties involved in this search emerge from Lars Eighner's recent study Gay Cosmos." His final chapter "Black Ganymede" (pp 197-224) is a study of the record of homosexual activity amongst black African communities, followed by "A Brief Cross-Cultural Survey" (pp 225-240) that documents homosexual activity amongst black African (and other) communitites. This record is valuable, yet a number of questions arise about the validity of the documentation

\footnotetext{
${ }^{3}$ Miller, p. 155.

4 See, for example, The Namibian, Aug. $21,1995, \mathrm{p} .6$.

${ }^{5}$ Lars Eighner, Gay Cosmos, New York: Masquerade Books, 1995.
} 
quoted, much of which is from anthropological writings of the colonial period. How reliable are these surveys, what relationship of trust existed between the information-seeker and the information-giver, and what methods were used to gather this information?

\section{Identity and human rights}

Questions of identity and of naming oneself "gay" or "lesbian" are important in the discussion of human rights and homosexuality in southern Africa. To demand to be protected against harassment and discrimination on the grounds of sexual orientation involves some degree of open acknowledgement of the nature of one's sexual preferences. In other words, it involves an act of naming oneself. For organisations that defend gay and lesbian rights, "coming out of the closet", that is, acknowledging one's same-sex preference, is a major item on the agenda. In this context two separate trends are apparent:

on the one hand, for many men who love men and women who love women, the acknowledgement of a "gay" or "lesbian" identity may seem either offensive or meaningless.

On the other hand, there is a growing number of men and women who do feel a strong need to acknowledge their identity as gays and lesbians and to claim their human right to be protected against discrimination and abuse.

The latter group is still predominantly white in southern Africa, but includes a growing number of black men and women.

Writers like Judy Gay and Limakatso Kendall have described loving relationships between women in Lesotho that have an erotic component, even though "erotic exchanges" among women may not be classified as "sexual", that is, ringed round with a term that sets them apart in kind from other exchanges. Kendall goes on to speculate that too much talk about homosexuality and more overt labelling of intimate relationships between women as "lesbian" or "homosexual" may make women afraid of entering into such relationshipsespecially if this naming is pejorative and thus discriminatory. ${ }^{1}$

These observations-and the very title of Judy Gay's paper, "Mummies and Babies and Friends and Lovers"suggest a tendency amongst African women who love women not to draw rigid dividing lines between friendships that have a sexual component and those that do not, and perhaps also not between the enjoyment of homosexual and heterosexual activity. To turn back to the two trends mentioned above, this would suggest the lack of a need to give separate names to different 'stations' on a continuous line that takes in love relationships, friendships, and affectionate relationships.

The book by Lars Eighner mentioned above contains some important recognitions on these questions. He argues, for instance, that "a homosexual-heterosexual axis is inadequate for expressing the range of human sexuality". ${ }^{2}$

There is an enormous diversity of same-sex eroticism in the Third world, says Peter Drucker in a 1996 overview, although reciprocal gaylesbian sexuality arose only in the nineteenth century. ${ }^{3}$

A point worth bearing in mind is the importance of children in African society. This could be one possible explanation to why there is

\footnotetext{
${ }^{1}$ Limakatso Kendall, "Looking for Lesbians in Lesotho", paper given at the Gay and Lesbian Studies Colloquium, University of Cape Town, Oct. 19-21, 1995; Judy Gay, "Mummies and Babies and Friends and Lovers", Journal of Homosexuality, Vol. 2, Nos. 3-4, Summer 1985, pp. 97-116.

2 Eighner, op.cit., p.44.

3 Peter Drucker, "Gay and Lesbians in the third World", The New Left Review, 218/1996, pp. 75-101.
} 
an acceptance-not necessarily expressed in words-of same-sex intimacy, but less understanding and acceptance of homosexual identity. one comes across situations in which same-sex sexual intimacy is tolerated and benevolently overlooked, as long as this is not made overt and public, so long as there is no risk it will interfere with a heterosexual marriage and prevent the bearing and raising of children. Same-sex intimacy is here tolerated, as long as it remains unnamed, and as long as it does not exclude sexual acts with members of the opposite sex. Without its label, there is in reality bisexuality in many African societies. Yet, there are also other voices, representing the second trend mentioned above, that express a need to acknowledge a gay and lesbian identity openly.

Amongst submissions to South Africa's Con stitutional Assembly was one by Ronald Louw, a gay activist and convenor of the Kwazulu-Natal Coalition for Gay and Lesbian Equality. Louw writes that while conducting research in Durban amongst black African men who love men, as discussion opened out he "continuously found an overwhelming sense of relief being expressed by African men that another dimension of their oppression was being lifted". ${ }^{1}$ It must be noted, too, that black gays and lesbians have had a visible presence, certainly in South Africa, for decades, and that they have taken part in gay and lesbian rights' organisations, though often experiencing conflict with their white counterparts. ${ }^{2}$

The culturally inherited concepts of identity thus vary. But we should like to emphasise that black and white women and men who are attracted to members of their own sex do not form absolutely separate groups, along racial lines. They form overlapping groups, but there are

\footnotetext{
1 Ronald Louw, submission to the Constitutional Assembly, Dec. 3, 1995.

2 See Gevisser and Cameron, pp. 52-55.
}

distinctions that depend on historical, cultural, and economic factors, of which racial oppression is one.

The questions about identity and naming reflect a debate already taking place in southern Africa, and one that will need to develop if people are to achieve full potential and adequate understanding of each other. We wish to stress, however, that though our booklet is concerned with issues of sexual behaviour, it is first and foremost a contribution to the discussion of human rights.

Gay and lesbian rights are sometimes looked upon as being different from other rights. Contributing to this view is a heritage of viewing homosexuality as a sickness, not something normal. The issue is also obscured by the tendency to identify homosexual behaviour as the primary source of AIDS, and the conflation of homosexuality with criminal acts, ranging from bestiality to child abuse.

Yet the identification of AIDS with homosexuality is not only illinformed, it is dangerous, as it obscures real knowledge about the disease and muddles any practical awareness as how to deal with it (see the appendix on AIDS facts).

The identification of homosexuality with criminal acts such as rape and child abuse is also dangerous, and offensive to gays and lesbians. Such acts are no more likely occur among homosexuals than in the heterosexual community.

There certainly is a problem of same-sex violence in prisons and men's hostels in southern Africa, but this tells more about the oppressive nature of these institutions than it does about homosexuality. A recent study in England about men raped by men came to the same conclusion as many previous studies on heterosexual rape: sexual violence is not about sex but about using humiliation to assert power. Only a minority of the men who raped men were homosexuals. 
The demand for rights of gays and lesbians not to be discriminated against because of their sexual orientation does not in any way mean condoning sexual exploitation and sexual violence, or asking for laws against these offences to be abolished.

If the priorities were set right we would not see campaigns against homosexual love between consenting adults, but a much greater concern with sexual violence and rape, which clearly is an offence against human dignity and freedom.

We have, in this chapter, raised some problematic questions about identity. We have suggested that when it comes to discussing men who love men and women who love women, one must avoid easy generalisations. But when it comes to the prohibition of discrimination and of harassment, then generalisation is easy enough. Here, homosexual and heterosexual behaviour fall into the same category, and the stand we take in this booklet is that human rights are essential for all. 


\section{Namibia-Ministers and Activists}

After the book fair in Zimbabwe, which was widely reported in the Namibian press and supplemented with interviews with Namibian gays, the debate was raised to ministerial level as two ministers joined the crusade against homosexuals.

"Homosexuality is like cancer or AIDS and everything should be done to stop its spread in Namibia", Hadino Hishongwa, the Deputy Minister for Lands, Resettlement and Rehabilitation was quoted as saying to the weekly New Era in early october. Homosexuality was alien to Namibian society, and those who engage in homosexual and lesbian relations should be "operated on to remove unnatural hormones", he said. "In an emphatic tone", the reporter records, "Hishongwa said he did not take up arms to fight for an immoral society, neither does he want his children to live in such a corrupt state". 1

The reporter had also solicited the opinion of Finance Minister Helmut Angula, who warned that homosexuality had infiltrated Namibian society, and might "lead to social disorder". In his view, the practice should be fought through intensified campaigns and political mobilisation.

The ministers' round was concluded by Nahas Angula, minister for Tertiary Education, Vocational Training, Science and Technology, who refused to comment, saying he would rather devote his time to better things than talking about the rights of homosexuals.

\footnotetext{
${ }^{1}$ Fred Mwilima, "Homosexuality is like Cancer or the AIDS scourge. Hishongwa blasts gays", New Era, 5-11 October 1995.
}

\section{The minister's lecture}

Helmut Angula returned to the issue a few weeks later in a lengthy article printed both in The $\mathrm{Na}-$ mibian and New Era. He repeats his attacks and also gives a lecture on the cause and origin of homosexual behaviour. ${ }^{2}$ He labels those who defend gay rights as "Eurocentrists and their fellow-travellers" and writes:

$$
\begin{aligned}
& \text {...homosexuality is an unnatural } \\
& \text { behavioural disorder which is alien } \\
& \text { to African culture. It is a product } \\
& \text { of confused genes and environmental } \\
& \text { aberration. In Judeo-Christian } \\
& \text { culture, it has generally been } \\
& \text { perceived as sinful. }
\end{aligned}
$$

He says he was misquoted on homosexuality as a product of Western culture, qualifying

that homosexuality is a product of industrialised society, where there is plenty of boredom and unbridled materialism, as well as liberalism bordering on anarchy.

"It is agreed" Angula continues, that homosexuals

in their overwhelming majority [lead] anti-social lives. They are abusers of alcohol, drugs, violent crime, child abuse and all type of evils, and are sources of deadly communicable diseases.

He repeats Hishongwa's idea that this horrible behaviour is due to a "gay gene", and sums up:

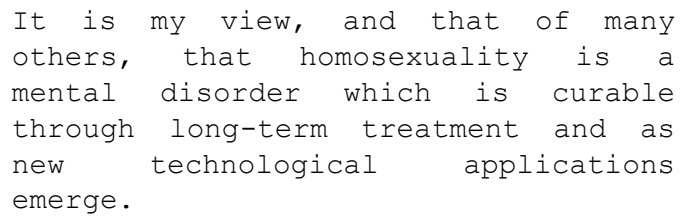

\footnotetext{
2 New Era, 21-27 December 1995, The Namibian, 10, 17, 24 November 1995.
} 
The "gay gene" theory had already provoked the Clinical Psychological Association of Namibia to say:

This is a foolish statement that reflects total ignorance of medical, surgical and psychological treatment techniques. No hormones can be removed surgically. ${ }^{1}$

The chairperson of the Association expressed concern that the misconceptions and gross misunderstandings expressed by Ministers Helmut Angula and Hadino Hishongwa could "be extremely harmful to the harmony and general well-being of the Namibian society".

\section{Gay rights and the liberation struggle}

Two fundamentally different views stand against each other in the Namibian debate. On one side, the two ministers describe homosexuality as a danger threatening the fruits of liberation. On the other side are those who see the recognition of gay rights as a logical extension of those human rights won in the struggle. Wolfram Hartmann and Andre du Pisani elaborate this view in the Namibian:

When Swapo waged its liberation effort from exile, the movement could always be sure of backing by gays and lesbians. As somebody who between 1975 and 1990 lived in Europe and engaged in gaylib and in AntiApartheid activity, I know that the solidarity movement had a disproportionately high percentage of gay and lesbian activists; no demonstration against apartheid went without a strong presence of gay and lesbian participation. Gays and lesbians share a very long history of persecution and therefore a very clear sense of injustice. One more question: Why are those nations of the West (against which is has become so fashionable to be nasty) who are liberal when it comes to homosexually loving men and women, also the nations who most vociferously and practically backed Swapo?

\footnotetext{
1 "Many Misconceptions about homosexuality", The Namibian, Oct. 20, 1995.
}

---Why should homosexually loving humans be excluded from the fundamental right of choice? Who is the Deputy to join Mugabe and deny us our humanness, dignity and human rights? Were these not exactly the issues that the Deputy's political party waged an armed struggle for before 1990? ${ }^{2}$

Namibia has not yet altered old laws against certain homosexual acts, which were inherited from the time that the country was occupied by apartheid South Africa. The constitution of independent Namibia (1990) does not mention "sexual orientation", but in its preamble guarantees "the right of the individual to life, liberty and the pursuit of happiness, regardless of colour, ethnic origin, sex, religion, creed or social or economic status". For the first time, these fundamental rights appear to come under attack. Hartmann, du Pisani and Steakley wrote to The Namibian :

Traditional targets of derisionwomen, children and foreigners-have seemingly been replaced by gays and lesbians. Has homophobia superseded xenophobia as Namibia enters a new phase of gay bashing, verbal for now, physical in the future? Are we witnessing the advent of politics of ostracism and displacement? ---

Homophobia in general and its southern African variant at present, constitutes a grave threat to both the integrity of the individual and more broadly to the entire citizenry of this region. This is so because homophobia propagates hatred of the very being of homosexually loving citizens and thereby tears at the fabric of civil society. At bottom it rests on the same logic of contempt that prompts all misanthropic acts: wife-battering, rape, child molestation, disregard of the elderly and so on. For that reason it also diminishes the dignity of the majority that happens to love heterosexually.

Ironically, the thesis that homosexuality is Western and

2 Wolfram Hartmann \& Andre du Pisani, "Let's get the facts straight on gays", Letter to the editor, The Namibian, Oct. 13, 1995. 
therefore by definition decadent, constitutes itself a peculiarly Western power discourse. This is so because it denies the richness of cultural and human experience.---

Psychologically defined, homophobia serves to bolster a male identity, disintegrating in the face of rising demands from women and other marginal social groups. ---

We are concerned that the recent expressions of homophobia may close down social and political space in our nascent civil society. ${ }^{1}$

\section{Gay and lesbian voices}

Meanwhile, the Namibian press also gave coverage to gay and lesbian organisations. Even before the book fair debacle, New Era had carried a story about homosexuals and lesbians planning to establish their own church to overcome the marginalisation they suffer in Christian and Muslim religions. ${ }^{2}$

After the ministers' intervention in the debate the "Sister Namibia collective", an organisation committed to the elimination of gender oppression, racism and homophobia, commented on the comparison of homosexuality with cancer and AIDS:

We fail to see any similarity. Cancer and AIDS are life-threatening diseases of the body, whereas lesbianism and homosexuality are alternative, life-enhancing, physical, emotional, and spiritual forms of love. ${ }^{3}$

In response to the claim that homosexuality was a western phenomenon the collective referred to research conducted by Kurt Falk who lived in Namibia for ten years early in this century:

\footnotetext{
${ }^{1}$ Wolfram Hartmann, Andre du Pisani \& James Steakley, "The politics of ostracism", Opinion, The Namibian, Nov. 17, 1995.

${ }^{2}$ Moses/Gowaseb, "Tired of marginalisation, they plan to go it alone. Lesbians, gays to erect own church", New Era, 13-19 July 1995.

3 "Sister roars back on gay rights", The Namibian, Oct. 10, 1995.
}

He found homosexuality in all cultural groups and lesbianism in most and provided a list of terms used in Oshiwambo, Otjiherero and Nama-Damara for homosexual acts and relationships and described relevant customs and practices.

This research was done at a time when Western countries were still criminalising homosexuality and trying to 'cure' gays and lesbians with electro-shocks and brain operations .

They pointed out that Western societies far from being permissive had a history of violent oppression of people who were 'different':

Thousands of homosexuals were killed together with Jews, gypsies, trade unionists and social democrats in German concentration camps during the reign of Nazism.

This puts the remarks made by deputy minister Hishongwa and Minister Helmut Angula into a frightening perspective which concerns us all. Tolerance and the recognition of the human rights of sexual minorities had only developed slowly in Western and other countries as gays and lesbian had dared to speak out openly and confront people with their homophobia.

The statement also notes the dismissive remarks by Minister Nahas Angula. Refusing to stand up for the rights of an oppressed group was "discriminating and oppressive in itself". 


\section{Botswana-Sharing the Blanket}

The press in Botswana reported on the book fair drama, and thereby opened a debate on homo-sexuality part of which raised much the same arguments and issues as in the Namibian debate.

\section{Thoughtful comments}

An unusually reflective intervention was made by Fred Dira, a columnist in the weekly paper Mmegi/The Reporter who felt compelled to join the debate in October 1995 after a controversial Botswana Democratic Party activist, Pelotetele Thlaodi had decided "to join the anti-gay fray". Thlaodi had launched a fierce attack against gay people at a BDP rally. Like Mugabe he had claimed that homosexuality was a foreign concept with no place in African society, and he had quoted the Bible to support his view that it was obnoxious. Fred Dira comments ${ }^{1}$ :

I must admit that I find homosexuality rather repugnant. But I have serious doubts about assertions such as those of Mugabe and Thlaodi that homosexuality is completely foreign to African culture. Homosexuality knows no political, cultural or colour boundaries. It is human behaviour which occurs in all societies, and to pretend that some societies or cultures are immune to it is ridiculous.

On the references to the Bible, Fred Dira writes:

...Thlaodi also quoted the scriptures to support his stand against homosexuality. That is all very well. But Thlaodi and others who think like him should remember that not everyone in this country believes in the teachings of the Bible.

\footnotetext{
1 Fred Dira, "Let's be realistic about homosexuality", Mmegi/The Reporter (Gaborone) Vol. 12, No. 41, 20-26 Oct. 1995.
}

There is therefore absolutely no reason why Christian beliefs should be permitted to dictate the kind of laws which should govern our society. Rather, our laws should be as realistic as possible and seek to accommodate the rights and interests of the different segments of our society. To facilitate this, we should seriously consider following the examples of other nations in handling the controversial issue of homosexuality. It is not in our interests to continue to bury our heads in the sand on this issue.

The Gaborone lawyer and opposition politician also adds a reflective, although somewhat contradictory note. On the one hand he speaks of a convenient strategy used by some imperialist countries to infuse their values in other societies under the guise of human rights. On the other hand he says that for the majority of Batswana, little is known about homosexuality, and changes must come slowly:

\begin{abstract}
The reason we have not questioned what beliefs we hold is because we have never had reasons to question them. --- I have not decided and cannot decide what position we ought to take concerning homosexuality because I do not understand it. --Don't you get us to change quickly. Educate us, give us time, show why we must change in that direction. I would like the laws that proscribe homosexuality/lesbianism retained until we are satisfied that we must change. But, please, when you come upon us, come with ease and understanding if you don't want us to react with resistance. ${ }^{2}$
\end{abstract}

\section{Telling it themselves}

What was new in the Botswana debate was the initiative to let Botswana gays and lesbians tell their own stories in the press. This gave a

\footnotetext{
2 Mmegi/The Reporter, 1995. Vol. 12, No. 39, 6-12 Oct. 1995.
} 
subjective and human perspective lacking in the policy debate.

One of the stories was that of a man reflecting on his experiences ${ }^{1}$ :

I had my first homosexual experience when I was 20 years old in serowe. GK was a friend of the same age from Mahalpye. He and I each had a girlfriend elsewhere in the village but we were not with them in July 1968. It was cold, we were sleeping outdoors as was then common for young men to do, and the two of us were sharing blankets and goatskins for warmth. Then, without any planning, we had a casual sexual experience using our hands. We finished, we rolled over; and we went to sleep. That is all that ever happened. Although we remained friends until I left Botswana, we never talked about it or repeated the experience.

This was not an isolated or unique occurrence. Southern African men of my generation will not be surprised at reading this account. Although what happened between GK and myself was certainly same-sex behaviour, it was not gay self-awareness or gay orientation or gay lifestyle. For GK it might have been a moment of curiosity or comfort or relief, probably nothing more. He went on to marry and have children, like me and everyone else we knew.

For me it was a step in a familiar direction-a step towards acknowledging that I had a second set of deep emotional longings. From my earliest days I had wanted to be close to boys as well as to girls. However, because a same-sex attraction was so despised by my family and society, the thought that I might be a homosexual always terrified me. Even after that night with GK, for seven years I sought out similar experiences while denying to myself that I was gay. ( I was in my late 20s before I felt comfortable with the idea).

Soon, one of those early experiences touched me deeply in a different way. For the first time, I felt really in love with a man., meaning that my head and heart became committed to him. A little older than I, this courageous tsala came from a small

\footnotetext{
1 "Sex without same-sex desires", from Botsnet, a discussion group over the Internet, reproduced in Mmegi/The Reporter, Vol. 12, No. 44, 10-16 Nov. 1995, p. 6.
}

outlying village but lived in serowe. My friendship with him was more unusual than the one with GK, but it was nonetheless quite permissible in the Tswana society of 1969. We spent our free time together, we shared blankets many times, and it gave us a great deal of pleasure to lie against one another and let the warmth flow between our bodies-and we never did anything sexual, not once.

Here was a case of same-sex orientation and of same-sex desire without same-sex activity, another possibility in the realm of human experience. I was in love, and he was in close affection, and for each of us it was a lot like having a (girl)friend, someone we spent our secret time with. ---

I tell these personal stories because they point to some general answers. The strongest argument is that: what a man does; what he wants do; what his self-concept is and the way he leads his life are four different but related things. It is not difficult to see that men in mine barracks, on naval ships, in prisons, in segregated boarding schools. and so on, are able to practice same-sex behaviour without having any deep same-sex desires. Indeed, as soon as they are in the company of women, they shift the focus of their attention right back to their women friends.

Thus their temporary same-sex activities are in no way related to genes or early child-hood upbringing or adult romantic failure or society's norms in general or being African or Western. They are simply a substitute for (unavailable) sex with women. They have occurred in most places at most times, and I do not think we need to consider them as a part of 'homosexuality' at all.

What preoccupies me is the deep inner longing to be close to someone, to touch, to share, and ultimately to have sex with him or her. ---

Following an interview with a gay Botswanan, a lesbian woman in Gaborone contacted the paper to tell her story:

At 21, Boitumelo (not her real name) is a beautiful young woman any hard working brother next door would be happy to lead down the aisle. In fact, she often dreams of the day she will exchange wedding vows and rings with her loved one with a promise of eternal happiness beckoning yonder. 


But there is just one hitch. The
law. The thing is Boitumelo is
lesbian, and the country's penal code
proscribes homosexuality. Until our
leaders see the need to change the
statutes, and this is very unlikely
in the foreseeable future,
Boitumelo's dream will remain just
that... a dream.--- birst became aware of my
'I firs
lesbianism about six years ago. I
didn't have any interest in boys.
There were some relationships, but
they never ended in bed. I would go
out with a guy for about a week, and
that would be the end of the story',
she says.
It was the pressure and fear of what
people would think of her, not love,
which landed Boitumelo in her past
heterosexual relationships. Finally
she got tired of living a lie and
broke off with her last boyfriend
three years back. She has since been
seeing a 26 year old woman with whom
she would like to settle.
Coincidentally, both women stay in
Gaborone with their unsuspecting
parents. 1 a

1 Mesh Moeti, "A lesbian comes out", Mmegi/The Reporter, Vol. 12, No. 41, 20-26 Oct. 1995. 


\section{South Africa-The Bill of Rights Debate}

\section{Rights}

7. (1) This Bill of Rights is a cornerstone of democracy in South Africa. It enshrines the rights of all people in our country and affirms the democratic values of human dignity, equality and freedom.

(2) The state must respect, protect, promote, and fulfil the rights in the Bill of Rights.

\section{Equality}

9. (1) Everyone is equal before the law and has the right to equal protection and benefit of the law.

(2) Equality includes the full and equal enjoyment of all rights and freedoms. To promote the achievement of equality, legislative and other measures designed to protect or advance persons, or categories of persons, disadvantaged by unfair discrimination may be taken.

(3) The state may not unfairly discriminate directly or indirectly against anyone on one or more grounds, including race, gender, sex, pregnancy, marital status, ethnic or social origin, colour, sexual orientation, age, disability, religion, conscience, belief, culture, language, and birth.

(4) No person may unfairly discriminate directly or indirectly against anyone on one or more grounds in terms of subsection (3). National legislation must be enacted to prevent or prohibit unfair discrimination. ${ }^{1}$

With this text of the Bill of Rights enshrined in the new constitution which was adopted on May 8, 1996 South Africa became the first country in the world to include a reference in the constitution to

1 South African Constitution, Chapter Two (as adopted by the Constitutional Assembly on May 7 and the Parliament on May 8, 1996). "sexual orientation" as one of the basic human rights to be protected against discrimination. It was first included in the Interim Constitution adopted in December 1993. The ANC had formally recognised lesbian and gay rights as part of its policy at its policy conference in May $1992 .{ }^{2}$

The South African Constitution was after its adoption referred to the Constitutional court, which examined its compatibility with the constitutional principles adopted during the transitional process. Some sections have been referred back, but the sexual orientation clause has not been an issue.

The government has started to put the principle into practice by recognising the rights of gays to serve in the military, and make a provision for a monitoring system in the armed forces to ensure that homosexuals are not victimised. Draft legislation on child care does not mention gender in regard to adoption, and legal recognition of matrimonial legislation is according to the Mail \& Guardian in August 1996, "only a matter of time". 3

\section{Multi-party backing of the constitutional clause}

There has been a remarkably broad official political party support for the inclusion of the clause on sexual orientation.

During the constitutional process for the interim constitution in 1993 all parliamentary parties but one proposed bills of rights including the rights of gays and lesbians for constitutional protection. The ANC and the Democratic Party proposals expressly made all discrimination on

\footnotetext{
2 ANC Policy Guidelines for a Democratic South Africa, as adopted at National Policy Conference, 28-31 May 1992.

3 The Mail \& Guardian, 2-8 Aug. 1996.
} 
the ground of sexual orientation unlawful, whereas the National Party initially proposed that only discrimination by the state should be mentioned. ${ }^{1}$

Only one of the political parties in the South African parliament, the African Christian Democratic Party (ACDP), has objected to the antidiscrimination clause.

\section{Shifting the perceptions}

Speaking at a conference on Human Rights Day 21 March 1995 launching the National Coalition for Gay and Lesbian Equality in the Gauteng region, Cheryl Carolus, the ANC Deputy Secretary General, said:

For the same reason that I oppose
racism and sexism I oppose
homophobia.
--- Our position has been to oppose
those who felt that we should go for
generalities in the constitution.
Because we have a past of such
oppression we feel the need to list
the areas where there is still
oppression.

But she issued a note of warning against any complacency that these rights had been won and accepted once and for all:

One must accept that the ANC is made up of very ordinary South Africans who bring with them many of the misinformed views, perspectives and prejudices that exist in society as a whole. Those of us that support the equality clause need to take cognisance of this [fact that] our views as the leadership are not necessarily the ones stated by the membership...

Many people that we love dearly-our parents, our brothers and sisters, our priests, our teachers are themselves quite often prejudiced when it come to the issue of homosexuality. We must accept that we are not just confronting bigots, people with horns, but that we need to take on this debate with our families and those closest to us.

1 Gevisser, Mark \& Edwin Cameron eds., Defiant desire. Gay and lesbian lives in South Africa, Ravan Press, Johannesburg 1994, p. 94-95.

2 Interview in Equality (Johannesburg), Nr 2, July-Sept. 1995, pp. 4-5.
Only then can we begin to shift the position in society.

\section{Inkatha does not follow Mugabe}

Mangosuthu Buthelezi's Inkatha freedom Party (IFP) did not take part in the work of the Constitutional Assembly after its walk-out in February 1995. But interestingly enough, IFP also had included an anti-discrimination clause in its proposal for the provincial constitution for Kwazulu/Natal, which was adopted in March 1996:

All citizens of the state of Kwazulu/Natal have equal social dignity, shall be equal before the law and shall share an equal right to access to political, social and economic opportunities irrespective of sex, race, colour, sexual orientation, language, traditions, creed, religion, political affiliation and belief, and social and personal status. ${ }^{3}$

Inkatha thus did not echo the Mugabe rhetoric on homosexuality as an imported Western phenomenon which threatens traditional values. One would perhaps have expected that it would have done so, given Inkatha's view of their primary enemy, the ANC, as an organisation that does not guarantee and respect the traditional lifestyle and culture of the Zulus.

The most prominent South African advocate of the argument that homosexuality is un-African is Winnie Mandela, who at her trial in 1991 for kidnapping and assault of a boy, Stompie, claimed that she had only saved him from a perverse priest. ${ }^{4}$

\footnotetext{
${ }^{3}$ KwaZulu Legislative Assembly, Resolution: Constitution of the state of Kwazulu/Natal, 1 December 1992, quoted in Gevisser \& Cameron, p. 96. The quoted text is the draft, not the final text. The final text has been referred by the Constitutional Court back to the KwaZulu Legislative Assembly, but the sexual orientation clause is not at issue.

${ }^{4}$ Gevisser \& Cameron, pp. 69-70.
} 


\section{The ANC leadership supports and cautions}

Cheryl Carolus, the Deputy Secretary
General of the ANC, on the other
hand, rejects the notion that
homosexulity is un-African:
We have to start working to explode
the myth that there are no
homosexuals or lesbians in black com-
munity. The reason why people haven't
had the courage to stand up is
because the debate has never picked
up in a substantive way in the black
community. Our struggle for the
equality clause must be won through
large-scale engagement with our com-
munities and not just with
politicians. 1

At the same time she also cautioned the predominantly white gay community that

...gay and lesbian organisations need to take into account the cultural environment in which the majority of South Africans function. They need to take on board questions of symbolism projected by the movement so that black gays and lesbians can feel comfortable in it and see it as a place where they can find back-up and support.

\section{Voices from the public in the constitutional debate}

The process of adopting a new constitution in South Africa has been unique in its popular participation. Hundreds of meetings have been held at grass roots level and in various organisations and sectors of society across the country, and an intensive campaign has been waged to encourage people to send or phone in their submissions to the Constitutional Assembly, both before the first draft was written, and as comment on the working draft.

The issues which propelled the largest number of South Africans to voice their opinion in the first stage were the status of the

\footnotetext{
1 Interview in Equality, Nr 2, July-
} Sept. 1995, pp. 4
Afrikaans language (half a million petitions), the secular character of the state, the death penalty, abortion, the right to self-defence and to own fire-arms, and the sexual orientation clause. There were about as many submissions in favour of inclusion of this clause as there were against it.

In the second stage submissions were invited on the working draft, which had been circulated in 4 million copies in December 1994 and January 1995. When the date for submissions closed on February 20, 1995 more than 20,000 new submissions had been received. This time around the campaign against the inclusion of sexual orientation had subsided, with 564 petitions opposing, and 7,032 petitions supporting the inclusion of the clause in the bill of rights ${ }^{2}$.

All submissions are available on the Constitutional Assembly website on the Internet ${ }^{3}$. We have used this to convey below some of the voices in this unique popular debate.

\section{Submissions against the sexual orientation clause}

The submissions against the sexual orientation clause almost invariably start and end with a moral condemnation of homosexuality as perverse, unnatural, and against God. The argument that it is "unAfrican" does not, however, appear in any submission we have seen. The campaigns against the sexual orientation clause resulted in 13000 petitions with the following or very similar wording:

I hereby strongly object to the legalisation of immoral and unnatural sexual lifestyles under chapter 3 Paragraph 8.2 of our interim constitution. The phrase "SEXUAL

\footnotetext{
2 Constitutional Assembly. Submissions Pack, 4th edition, 20 March 1996, p. 6. 3 It can be reached at http://www.constitution.org.za. The submissions quoted in the following text are found in the searchable data base for submissions.
} 
ORIENTATION" must be deleted from our present constitution and must NOT be included in the final constitution that is being drafted. Homosexuality, lesbianism, sodomy and bestiality are unnatural, abnormal and immoral and do not deserve any constitutional protection under clauses like "sexual orientation."

Objections to the equality clause often refer to God, as in the following statement from the Kwasizabuntu ministers' conference (9 June 1993):

On behalf of the Kwasizabantu
Ministers' Conference we want to
express dismay about the recent
proposal by the negotiators to
consider a non-discrimination law
towards sexual orientation. "Sexual
orientation" is a euphemism for
perversion; homosexuality and
lesbianism. To afford special
protection to a lifestyle that is
expressly forbidden by the Word of
God would be disastrous for our
country.

The submissions against the sexual orientation clause often conflate homosexuality with all kinds of perverse behaviour: bestiality, prostitution, drug abuse, having sex with idiots and imbeciles.

The constitution makers themselves were satisfied, however, that the term "sexual orientation" could not be misunderstood. Kevin Botha of the Equality Foundation wrote in a statement:

Despite diligent search we have been unable to find a single instance in any jurisdiction employing the term sexual orientation which includes in the definition of sexual orientation paraphilia activities such as zoophilia (bestiality), paedophilia (sexual activity with minors) or sex with imbeciles and idiots. Our own research indicates that sexual orientation is the preferred terminology and is consistently employed in numerous jurisdictions to describe only the sexual orientation of heterosexuals, bisexuals and homosexuals.

\section{Submissions for the sexual orientation clause}

The submissions arguing for the inclusion of the sexual orientation clause are more varied.

The Democratic Party in Durban (20 May 1995) identifies the clause as part of general antidiscrimination:

The Democratic Party has consistently opposed and fought injustice and discrimination in every form. We are therefore particularly concerned at recent attempts by a small minority to tamper with section 8(2) of the interim Constitution. ... Discrimination in any form, including on the basis of sexual orientation, must be rejected and we hereby give notice of that fact.

The Human Rights Lawyers in Pietermaritzburg in a submission on April 19, 1995 endorsed by a number of legal advice centres in the Durban area, argues for equality and against legislation on religious doctrine:

The purpose of law in South Africa should be to protect the rights and freedoms of all persons.

South African law has a history of being coercive with regard to human relationships. The Immorality Act of 1957 legalised attitudes of intolerance in South Africa. In an open and democratic society there should be no room for intolerance. The struggle for tolerance in south Africa has a broad foundation encompassing, alongside race, the full recognition of sexual orientation as a human right.

Based on the principle of equality, all rights and freedoms should be guaranteed to all human beings. With the exception of the exploitation of power relationships, there is no justifiable reason for state intrusion into private nonreproductive consensual adult relations. The autonomous right to privacy with regard to sexual orientation should be protected as a fundamental human right. Arguments against sexual orientation have foundation in religious doctrine and moral theories. The law should not legislate on morality because any 
prescription by law leads to a limitation on the extent of freedoms. Sexual orientation is ineradicable, therefore the law should not limit liberties with regard to sexual orientation.

There were, however, also Christian arguments in favour of the clause. Bishop Mmutlanyane Moqoba of the Methodist Church ( 8 June 1995) said:

As a Church we are committed to the dignity and worth of all people and to their equality in their sight of God. We find it irrelevant to claim that some people who are deemed to be sinners are therefore to be discriminated against-because we are all sinners.

I appeal to you to resist any attempt to limit the recognition of the rights of all people, which is the genius of the proposed Constitution, and retain the 'sexual orientation' clause.

Another strong Christian statement came from the Anglican Archbishop of Cape Town, Desmond Tutu (2 June 1995) :

Within the Church of Christ, and indeed amongst adherents of other faiths, there is much debate and difference of opinion on the question of homosexuality. The theological and ethical issues are complex and far from resolved. It is indisputable, however, that people's sexual nature is fundamental to their humanity.

The apartheid regime enacted laws upon the religious convictions of a minority of the country's population, laws which denied gay and lesbian people their basic human rights and reduced them to social outcasts and criminals in their land of birth. These laws are still on the statute Books awaiting your decision whether or not to include gay and lesbian people in the "Rainbow People" of South Africa. It would be a sad day for South Africa if any individual or group of law-abiding citizens in South Africa were to find that the Final Constitution did not guarantee their fundamental human right to a sexual life, whether heterosexual or homosexual.

The lawyers' committee of the Equality Foundation (21 June 1993) points out the educative role of the inclusion of the sexual orientation clause:

...enumeration would enhance the educative role that a bill of rights would play in underpinning a culture of tolerance and understanding. This educative role is a powerful tool in aiding reconstruction generally and cannot be underestimated in the context of groups which have traditionally suffered from discrimination.

\section{Personal testimonies}

Many individual submissions by gays emphasise their own demand for protection. Ronald Louw of the University of Natal writes:

...As a gay lecturer in law, I was
immensely proud of our new
Constitution considering its broad
inclusive nature and the fact that it
signalled the end of irrational
intolerance towards gays and
lesbians.

...The oppression of gays and lesbians has been largely hidden in our society because of the greater oppressions of race and gender. Now that we are making a concerted effort to overcome the worst possible forms of oppression, we should not lose sight of the fact that people are oppressed in many other ways. As a privileged white male I have in the past been reluctant to complain too loudly of my oppression as a gay person so not to lose sight of the fact that millions of others suffered a far greater oppression than I could ever know. But now is the time to recognise those other forms of oppression so that everybody in south Africa may enjoy the full benefits of liberation.

I am sure that the Committee will be receiving many submissions calling for the scrapping of the sexual orientation provision. For those people, the provision does not impinge directly on their lives. However, for gays and lesbians, the provision affects our lives in a very real and direct way. Surely the mere opinions of the former should not prevail over the lives of gays and lesbians?

There were among the submissions many very personal letters, among which we find Justin C. Waldman 
writing on Jan. 15, 1996 to the Constitutional Assembly:

It is with great relief that I see that you have retained the sexual Orientation Clause in the proposed Constitution. Thank you. I had intended to write to you sooner but there was little more than "Thank you" that I wanted to say and so time slipped by. However, it was only yesterday that it was brought home to me how much I as a gay man, need the protection of the Constitution as I was abused anonymously over telephone by a less than friendly individual. Apart from the considerable upset I felt, I had some solace in the fact that there is at least a constitutional guarantee of equality, and therefore protection, for me in the constitution. It was this very abuse of my basic human rights by some irrational and hate-filled person which makes it so very necessary that the Sexual orientation clause be retained in the final document. I wish you all the best in your work and thank you for your wisdom.

\section{Women against discrimination}

The submissions also contain a number of appeals against discrimination by women, who are obviously not members of the gay and lesbian community. Mrs Leslie Kahn, who signs "Straight but not narrow" writes:

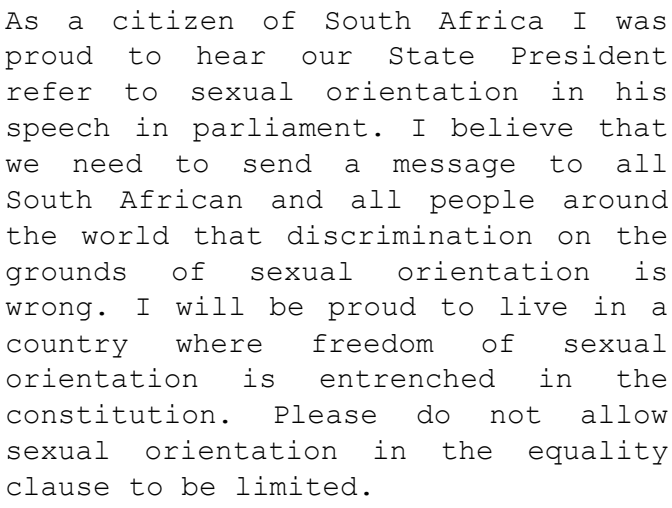

The last of our samples of submissions on the South African constitution comes from Mrs Sonia Mbabala from the township of Gugulethu:

I am a married woman with a family and I live here in Gugulethu. I want to address the whole issue within the Constitution that there are some organisations that are refusing to grant people the rights that are due to them, especially the right for them to live the way they choose to live. For example the issue of 'Gays'. I see no reason why people should be discriminated and not practise what they want to be. Today in South Africa everyone is free people are free and do not want to see themselves worrying others. There is a need for people to love gay people.... Gays are people too and they should also be allowed to live freely too in their own country. 


\section{Homosexuality and the Law-A Global Overview}

This chapter aims at giving an overview of homosexuality and the law globally, so as to put the discussion and developments in southern Africa in perspective. ${ }^{1}$

Despite the recurrent labelling of homosexuality in the debate as "alien" and "unnatural" there is today a consensus among those who have carried out research on the topic that homosexuality exists in all societies. It is perhaps worth remembering that research on 'sexuality' in its social dimensions is relatively new. There have been, and to a large extent still are, many more preconceived ideas and ideologically tainted assertions and prejudices about sex and sexuality than there is knowledge.

\section{Increasingly a human rights issue}

If there are homosexuals in all societies they can be seen as minorities, and given the persecution they have faced, they constitute minorities which need legal protection against discrimination. This is the general reasoning behind the increasing and fairly recent tendency to view homosexuality as a human rights issue.

A sign of this was the decision by Amnesty International in 1991 to consider the complete prohibition under criminal law of sexual acts between persons of the same sex as an infringement of human rights. Since then Amnesty has adopted as

\footnotetext{
${ }^{1}$ We wish to thank Ron Buckmire, Anjie Rosga, Franklin Weston, Timothy Ross Wilson, Bernie Hamilton, Annebeth Rosenboom, John Terry, William A. Courson, Margarita Lacabe, Rachel Rosenbloom, Suzanne Goldberg, Sydney Levy and Björn Skolander for helpful assistance with material and reading suggestions for this chapter.
}

prisoners of conscience persons imprisoned under such laws. The first such gay prisoners of conscience were two men convicted in Rumania.

In the legal discussions preceding the adoption of the new constitution in South Africa it was stated that "sexual orientation" could be included in the bill of rights outlawing discrimination against minorities only if homosexual persons could be seen as constituting "a natural group". It was agreed that they did. A natural group is a group with characteristics that the members do not choose themselves.

This is a view of homosexuality that demands a reconsideration of many conventional notions. For example, if homosexuality is not contagious and the homosexuals are, and remain, a minority, they will not pose any significant threat to "family patterns" ${ }^{2}$

A forceful expression of this process of reconsideration is expressed by Archbishop Desmond Tutu of the Anglican church of Cape Town in a foreword to a new book on Christian lesbians and gays:

...we spurn them, we shun them, because we are all caught up in an acknowledged or a tacit homophobia and heterosexism. We reject them, treat them as pariahs, and push them outside the confines of our church communities, and thereby we negate the consequences of their baptism and ours.

We make them doubt that they are the children of God, and this must be nearly the ultimate blasphemy. We

\footnotetext{
${ }^{2}$ See also Eric Heinze, Sexual Orientation: A Human Right-An Essay on International Human Rights Law, Dordrect, Martinus Nijhoff 1995, pp. 50 ff. i.a. and Robert Wintemute, Sexual Orientation and Human Rights, Oxford, 1995, pp. 61-90 i.a.
} 
blame them for something that it is be-coming increasingly clear they can do little about. Someone has said that if this particular sexual orientation were indeed a matter of personal choice, then gay and lesbian persons must be the craziest coots around to choose a way of life that exposes them to so much hostility, discrimination, loss, and suffering.

To say this is akin to saying that a black person voluntarily chooses a complexion and race that exposes himor herself to all the hatred, suffering, and disadvantages to be found in a racist society. Such a person would be stark raving mad....

It is only of homosexual persons that we require universal celibacy, whereas for others we teach that celibacy is a special vocation. We say that sexual orientation is morally a matter of indifference, but what is culpable are homosexual acts. But then we claim that sexuality is a divine gift, which used properly, helps us to become more fully human and akin really to God, as it is this part of our humanity that makes us more gentle and caring, more selfgiving and concerned for others than we would be without that gift. Why should we want all homosexual persons not to give expression to their sexuality in loving acts? Why don't we use the same criteria to judge samesex relationships that we use to judge whether heterosexual relationships are wholesome or not? ${ }^{1}$

\section{Changing discourses}

Views on and legislation against homosexuality have always been significantly informed by discourses other than legal considerations of law and order. In the Western countries Christianity has historically given the ideological leadership. The same is the case in the former colonies of black Africa where both official ideology and public discussion have to a large extent been shaped by the spread of Christianity through mission activities. A very large proportion of the political leaders in black Africa today have received part or all of

\footnotetext{
${ }^{1}$ Marilyn Bennett Alexander and James Preston, We Were Baptized Too: Claiming God's Grace for Lesbians and Gays, John Knox Press (London) 1996, foreword.
}

their formal schooling through mission-run schools.

The anti-discrimination plea of Christians such as bishop Tutu also comes up against the tradi-tional views still widely held in the established Christian churches, where references to the Bible and an emphasis on "family values" are used to condemn homosexuality. In this context, homosexuality is viewed as sin, or at best as a sickness, and tolerance goes no further than seeing homosexuals as lost sheep, who must be taken care of and led to the right path. Or, as some Christian leaders in Zimbabwe cautioned: we want to eradicate homosexuality, not the homosexuals.

In almost all Christian churches in the last decades, fierce debates have raged on the issue of homosexuality. In Finland, for example, the Archbishop of the state Lutheran Church faced a campaign in the early 1990s to unseat him because he refused to condemn homosexuality as a sin.

Desmond Tutu represents modern trends in Christianity which emphasize tolerance rather than the fear of God, and who want to see the role of the church in society as pioneer in the struggle for rights of those who are discriminated against and oppressed. Healing and cooperation across ethnic, national, religious and other borders are important objectives for these trends.

These trends are counteracted by fundamentalist trends, which have often put the fight against rights for homosexuals, alongside the fight against abortion rights for women, high on their agenda. The anti-gay and anti-abortion crusade is particularly well organised and well-funded in the United States. One expression of it is a current campaign to get a federal law to outlaw all state laws which permit same-sex marriages or legalised partnerships. This campaign suffered a major setback when the U.S. 
Supreme Court on May 20, 1996 "in its most significant gay-rights case in a decade" ruled that a colorado constitutional amendment forbidding laws protecting homosexuals from discrimination violated the constitutional right to equal protection. ${ }^{1}$

Traditional views on

homosexuality have been supported and informed also by medical discourse. Homosexuality was for many decades seen as a disorder, although there is no scientific basis for this classification. A physician in Germany by the name Krafft-Ebbing had introduced this thinking on the basis of his study of homosexual prisoners, whom he labelled as abnormal from birth, and in need of medical treatment. ${ }^{2}$ There have been in the 20th century clinical psychologists who offered their services to "cure" homosexuals, while others refused, and rather tried to help their homosexual patients to accept their sexual orientation.

In the 1970s the view of homosexuality as a disorder began to be replaced by an acceptance of the fact that same-sex attraction was normal to a minority of people in most if not all societies. In 1973 the U.S. PsychiatryAssociation deleted homosexuality from its handbook on mental disorders. In Sweden homosexuality was taken off the official list of diseases in $1979 .{ }^{3}$ Homosexuality was taken off the list of diseases by the World Health Organisation (WHO) as late as 1993. Another discourse which contributes to changing views on 'gay rights' is the increased impor-

\footnotetext{
1 Laurie Asseo, "Constitutional Amendment Violates Homosexuals' Rights, Justices Rule", Wall street Journal, May 21, 1996.

2 See Homosexuella och samhället ("Homosexuals and society"), Statens offentliga utredningar 1984:63, Stockholm 1984 (a Swedish state commission report), pp. 559-560.

${ }^{3}$ The list is produced by the National Board of Social Services (Socialstyrelsen).
}

tance attached to developing a human rights culture internationally. The adoption by the United Nations of the Universal Declaration of Human Rights in 1948 was one step in this direction.

But the idea of the universality of human rights has not always been firmly rooted. Despite the fact that the document was viewed at the preparatory stage as being inspired by fundamental values in all major religions of the world, voices were soon raised to the effect that the human rights were just a cloak for Western bourgeois concepts of individualism. The socialist countries, led by the Soviet Union, stressed socio-economic improvements rather than individual freedoms and the right to political dissent. In Africa the one-party state and ensuing limitations on individual rights and political opposition was justified by the need to unite against underdevelopment and for national unity.

Individual freedom and the rights of groups to form an opposition has been increasingly stressed as significant for development globally as authoritarian rule has come into disrepute, whether in the form of military dictatorship or one-party rule. Those who continue to defend authoritarian rule and values often speak of cultural and groups rights based on traditions and claim that they are incompatible with individual rights.

Finally, we should mention the growth of gay and lesbian organisations who work for "gay rights" as a factor changing general views about homosexuality. In southern Africa the gay and lesbian organisations in South Africa have been very active both within the ANC and in the con-stitutional debate. On the international scene, the International Lesbian and Gay association (ILGA) is the most important organisation working for the rights of homosexuals. It is a sign of the significant and recent 
changes in the discourse on homosexuality that ILGA was received in May 1996 by the Vice-Chairman of the Commission of the European Union of the European Comm-unity. ${ }^{1}$ The European Parliament had earlier commissioned a report on the situation and rights of gays and lesbians in Europe, and in 1994 adopted a resolution calling for all members states to abolish legal criminalisation and discrimination against homosexuals. ${ }^{2}$

\section{Towards a definition of gay rights}

"Gay rights" can mean many things. In order to clarify the discussion we will distinguish between four levels of rights, from minimum to maximum:

(a) Decriminalisation of sexual acts between women and men of the same sex, providing that the acts take place between consenting adults, without offending public decency .

(b) Freedom of expression when it comes to speaking and writing in public about homosexuality, without offending public decency.

(c) Legal protection against discrimination on grounds of sexual orientation.

(d) Recognition of equal rights for gay and lesbian relationships as compared with heterosexual relationships.

\section{(a) Decriminalisation}

Where sexual acts between persons of the same sex are outlawed and punishable this in many cases covers only men.

Homosexual acts are today decriminalised in most European countries, with the notable exception of Romania, dubbed as "the most homophobic country in Europe".

some countries in Africa, including southern Africa, do not have any laws against homosexuality

\footnotetext{
1 ILGA Press release, May 7, 1996.

2 Resolution on equal rights for homosexuals and lesbians in the EC, A3$0028 / 94$.
}

on their books, for example Botswana, Lesotho, Swaziland.

Homosexual acts between men are illegal in Angola, Mozambique, Malawi, Namibia, Tan-zania, Zambia, Zimbabwe, and according to the old laws in South Africa, which remain on the books until they are found unconstitutional or are repealed. Female homosexuality is not mentioned in the laws of any of these countries. ${ }^{3}$

\section{(b) Freedom of expression}

Freedom of expression is what the debate at the Zimbabwe Book Fair was basically about. The reasoning of the government must have been that since homosexuality was outlawed one could not speak about it in public either. But not all manifestations of homosexuality are in fact outlawed. Partly the reaction of the government was based on the mistaken assumption that it was taking preventive action against offences against public decency, but as one participant dryly observed: "I don't see why they assume that the gays want to do it in public".

Lawyers consulted by the Zimbabwe Book Fair Trust have apparently come to the conclusion that the legal provisions for freedom of expression actually do allow information on homosexuality and advocacy of gay rights. It is on this basis that the Trust promises to take future government interventions of the kind taken in 1995 to court if necessary.

In some countries, for example in England and Finland, there are laws prohibiting public expression of the "advocacy" of homosexuality. Although these laws are difficult to interpret, in Finland a law of this kind was earlier used to suppress public information about

\footnotetext{
${ }^{3}$ Index on Censorship No.1, 1995, pp. 195-204, Aart Hendriks, Rob Tielman \& Evert van der Veen, The Third Pink Book; A Global View of Lesbian and Gay Liberation and Oppression, Prometheus Books, New York, 1993, pp. 252-342.
} 
homosexuality. Even the appearance in an interview of a person confessing to be gay and happy about it was interpreted as an incitement, falling under the law against "public encouragement of unchastity between persons of the same sex", punishable by 6 months to 4 years' imprisonment. ${ }^{1}$. Today, the law is no longer invoked and the public debate in Finland about homosexuality, and also the visibility of gays and lesbians, are considerably greater than ten years ago.

\section{(c) Legal protection against discrimination}

We differentiate here between four basic kinds of legal protection against discrimination on the grounds of sexual orientation, which we first list and then discuss in detail:

(i) General declarations of human rights, which can be interpreted as also covering homosexuals.

(ii) Enumerated bans of discrimination with explicit reference to sexual orientation or specific national laws outlawing discrimination on the grounds of sexual orientation.

(iii) Legislation outlawing discrimination in specific fields, such as the labour market.

(iv) Legislation specifically outlawing homophobic violence.

(i) General declarations of human rights

Many of the codes in international law belong to the first category, and will be discussed in the next section.

(ii) Enumerated bans of discrimination with explicit reference to sexual orientation

The farthest reaching declaration of principle is the inclusion of sexual orientation in the constitution in

\footnotetext{
${ }^{1}$ Article 9 (as amended in 1971), chapter 20 of the Penal Code of Finland.
}

an enumerated list of grounds on which discrimination is outlawed. We have seen South Africa as the first country in the world to have taken this step when including "sexual orient-ation" in its Bill of Rights, which is part of the new constitution.

It is interesting to note that the German Democratic Republic ("East Germany") was close to becoming the first country to introduce a constitutional sexual orientation clause as early as 1989. But before this was enacted the country was merged with the German Federal Republic (West Germany").

In the same week of May 1996 that South Africa adopted its constitution, the Canadian Human Rights Act was amended to include a sexual orientation clause. In 1996 the right to express one's sexual orientation was established as "a basic right" in Spain. ${ }^{2}$

A constitutional antidiscrimination or equality clause is not necessarily the best guarantee against legal discrimination, as Kees Waaldijk points out. ${ }^{3}$ In South Africa the Constitutional court can review the constitutionality of parliamentary legislation, but in some countries the courts have little or no power to do so. ${ }^{4}$

"Discrimination" and "equality" are vague concepts which leave a wide scope for interpretation, Waaldijk writes, and equality is usually interpreted as only prohibiting distinctions which are not based on reasonable and objective justification. In France, for example, the Constitutional council held in 1980 that the still

\footnotetext{
2 Kom Ut (Stockholm), 1/1996, p. 17.

${ }^{3}$ Waaldijk, Kees \& Andrew Clapham, eds., Homosexuality: A European Community Issue, European Human Rights Foundation, Martinus Nijhoff Publishers, International Studies in Human Rights Vol.26, Dordrecht, the Netherlands 1993., pp.78-79.

4 There is no such power in Luxembourg or the Netherlands, and limited power only in Belgium, Denmark and France.
} 
applicable different age limits for heterosexual sex and lesbian and gay sex did not violate the principle of equality, because they were acts of a different nature. ${ }^{1}$ Waaldijk concludes that specific antidiscrimination laws or the use of the international law of human rights can be more effective than a constitutional equality clause.

National bans on discrimination on the grounds of sexual orientation have been enacted in Norway, Sweden, the Netherlands, Israel, Canada, Denmark, Finland, Slovenia, France, Ireland and New Zealand. ${ }^{2}$ About a dozen of the states constituting the United States of America explicitly ban discrimination on the grounds of sexual orientation in their state laws.

(iii) Legislation outlawing discrimination in specific fields, such as the labour market

In 1984 a European Parliament Resolution on Discrimination in the Workplace was passed, which called for an end to both de facto and de jure discrimination against homosexualsboth on national levels and on the European Community level. ${ }^{3}$

France was the first European country to introduce legislation prohibiting anti-homosexual discrimination in the field of employment, followed by the Netherlands, Norway, and Sweden. ${ }^{4}$

\footnotetext{
${ }^{1}$ Waaldijk \& Clapham, pp. 79, fn. 22.

2 Rachel Rosenbloom of the International Gay and Lesbian Human Rights Commission in San Francisco, as reported in New York Times, May 10, 1996 mentions Norway, Sweden, the Netherlands, Israel, Slovenia, and New Zealand. Waaldijk \& Clapham also list France, Denmark and Ireland, p. 79. The inclusion of Ireland is apparently based on the ban on incitement against gays, whereas a general equal status bill was defeated in 1992. An anti-discrimination bill was defeated in the United Kingdom in 1983. Ron Buckmire supplied a list on the Internet "queerlaw" forum on May 17, 1996 containing also Canada, Finland and Denmark.

${ }^{3}$ In Waaldijk \& Clapham.

${ }^{4}$ Waaldijk \& Clapham, p. 105.
}

Finland enacted in 1996 a law banning discrimination against homosexuals in the labour market, and the Danish ministry of labour will propose a similar law. ${ }^{5}$

Apart from national legislation, the banning of discrimination can also be effected by explicit rules and declarations taken by employers. For example, a number of universities in the US have declared that they will not discriminate on the grounds of sexual orientation in their employment practices.

(iv) Legislation specifically outlawing homophobic violence

There is unfortunately an increased need for legislation against violence used against gays and lesbians solely on account of their sexual orientation, as frequent acts of assault, particularly against gay men, are being reported.

Ireland introduced a Prohibition to Incitement to Hatred Act in 1989, which makes it a criminal offence to incite hatred on the basis of sexual orientation. ${ }^{6}$ In Spain violence against homosexuals can be punished with 4 months' to 4 years' imprisonment, according to a law enacted in 1996. ${ }^{7}$ Similar laws have been proposed in many countries' parliaments.

\section{(d) Recognition of equal rights for gay and lesbian relationships as compared with heterosexual relationships}

Most countries have criminal laws which make it a criminal offence to have sex with persons under certain ages. Where these age limits are set differently for homosexual acts than for heterosexual acts equal rights are not recognized. In many countries the age limit is set lower for homosexual intercourse than for heterosexual intercourse, for example, the United Kingdom, Greece, Ireland. Equal age limits have been

\footnotetext{
5 Kom Ut (Stockholm), 1/1996, p. 17.

${ }^{6}$ Waaldijk \& Clapham, p. 80.

7 Kom Ut (Stockholm), 1/1996, p. 17.
} 
legislated in Belgium, the Netherlands, Portugal, France, Spain, to name a few.

Another type of laws falling into this category are laws which give homosexuals living together contractual rights comparable to those accorded to heterosexual couples. Registered partnership for homosexual couples has been made possible by laws in Denmark (1989), followed by Norway (1993), Sweden (1995), and Hungary (May 1996) ${ }^{1}$. Similar laws have been proposed and will be discussed in the near future in the legislative assemblies of Iceland, Finland, Holland, the Czech Republic, and the state of Hawaii. One of the effects of these laws is that a homosexual can inherit his/her partner's estate. In none of these countries can homosexual partnership be sealed by the church ritual of marriage, but many ministers are prepared to give homosexual partners their blessing in a ceremony.

\section{Homosexuality in international law}

Where national laws do not explicitly ban discrimination against homosexuals their only recourse to legal protection is the appeal to International Human Rights Law. This includes all multilateral agreements in the area of human rights, and some regional agreements, and some covering nonregional groupings, such as the Commonwealth.

Some agreements are "soft law", that is, recommendations but not binding upon the signatories, and with no legal mechanism through which breaches can be appealed against. The Universal Declaration of Human Rights adopted by the United Nations is an example of this.

Other agreements are "hard law" and binding for those who have signed the agreements. The various

${ }^{1}$ Associated Press, May 21, 1996. covenants initiated by the Economic and Social Council (ECOSOC) under the General Assembly belong to this category. Relevant in the context are, among others, the International Covenant on Economic, Social and Cultural rights, and the International Covenant on Civil and Political Rights (both from 1966).

"Sexual orientation" is not explicitly mentioned in any instrument of international law. In the UN Charter protection against discrimination is agreed upon in four specified areas: race, sex (gender), language, and religion. This is "a closed list" of rights. Other agreements have "open lists" of rights-the enumeration of grounds of protection against discrimination in these agreements is not exhaustive.

Both 1966 Covenants refer to "race, colour, sex, language, religion, property, birth or other status." (our italic). The African (Banjul) Charter of Human \& People's Rights of 1981 has a similar wording (although adding 'ethnic group' and having 'fortune' instead of 'property'), and also ending with "or other status". Peter Nobel, Sweden's first Ombudsman against discrimination and specialist in international law summarizes:

It can clearly be argued and there is little doubt about it among leading Human Rights experts that individuals with a sexual orientation other than the majority are included and that they shall be protected from discrimination . ${ }^{2}$

It can be mentioned that a case has been brought to the African Commission on Human \& People's Rights, where the petitioner argues that the government of Zimbabwe in its anti-gay campaign has violated 15 of the 25 articles in the African Charter of Human \& People's Rights. ${ }^{3}$

\footnotetext{
2 Written communication, May 1996.

3 "Complaint Relating to Violation(s) of Certain Provisions of the African Charter of Human \& People's Rights. by the Republic of Zimbabwe from The Magnus
} 
Two other provisions in the Universal Declaration of Human Rights of relevance to the legal protection of homosexuals are the rights to privacy and to equal protection. There has not, however, so far, been any judicial decision by an international or national court which has specifically addressed how these clauses in the Universal Declaration of Human Rights should apply to lesbian and gay individuals. ${ }^{1}$

Similar clauses are also found in many other international law instruments, such as the International Covenant on Civil and Political Rights (ICCPR) referred to above. On April 4, 1994, the United Nations Human Rights Committee ruled that the Australian state of Tasmania violated the privacy and non-discrimination provisions of the ICCPR with its sodomy law. This ruling, in Nicholas Toonen vs. Australia ${ }^{2}$, was an important step towards decriminalisation of samesex contacts between consenting adults. As Wilets points out, this has an importance far beyond decriminalising homosexual activity, as courts (and, one may add, political leaders) often fail to make a distinction between activity and status. Criminalisation of homosexuality has been invoked to justify a wide range of human rights violations against lesbians and gays. ${ }^{3}$

Prior to the Toonen case, the European Court of Human Rights, with jurisdiction over all countries in the Council of Europe, had ruled that sodomy laws violate "the right

F. Hirschfeld Center for Human Rights, Montclair, New Jersey.

1 James S. Wilets. "Using International Law to Vindicate the Civil Rights of Gays and Lesbians in United States Courts", Columbia Human Rights Law Review, Fall 1995, Vol. 27, No.1, p. 48 .

${ }^{2}$ UN Hum. Rts. Comm., No 488, UN Doc. $\mathrm{CCPR} / \mathrm{C} / 50 / \mathrm{D} / 488 / 1992$. See Wilets 1995, pp. 33-34., 36 .

${ }^{3}$ Wilets 1995, p. 35, footnote 7 . to privacy" included in the European Convention for the Protection of Human Rights and Fundamental Freedoms, which had been adopted in 1953, and amended in 1970 and 1971. This ruling was laid down in three cases, Dudgeon v. Northern Ireland (1981), Norris v. Ireland (1988), and Modinos v. Cyprus (1993). ${ }^{4}$

Not all discrimination and oppression can be fought through recourse to the law. Human rights advocates focus almost exclusively on state actors rather than on private parties, which excludes many aspects of life, especially for women in general, including lesbians. A notable exception was the Declaration on the Elimination of Violence Against Women, adopted by the General Assembly in December 1993. It defines violence occurring in the family, in the community, and "perpetrated or condoned by the state" as a violation of human rights. ${ }^{5}$

This chapter deals with the legal aspects. But it is well to remind ourselves of the complex relationship between the law and society's norms. Laws not only stipulate punishment for breaches of what society sanctions and wants to protect, they also set standards. But the social acceptance of homosexuality depends on many other factors as well, such as the general atmosphere of tolerance, views on sexuality, the tone set by leaders and opinion-makers, and the visibility of gays and lesbians themselves. Legislation is not a sufficient precondition for nondiscrimination, and sometimes not

\footnotetext{
4 Claudia Roth, On Equal Treatment of Lesbians and Gay Men in the EC, Preliminary draft report July 17, 1993 on behalf of the Committee on Civil Liberties and Internal Affairs, section 2 .

${ }^{5}$ Miller, Alice M. \& AnnJanette Rosga \& Meg Satterthwaite, "Health, Human Rights and Lesbian Existence", Health and Human Rights, (Harvard School of Public Health, Cambridge, Mass.) Vol.1, No. 4, 1996, pp. 429-448.
} 
even a necessary requisite, since

laws that are felt to be out-dated or irrelevant are often ignored and not invoked. The struggle for gay rights as part of human rights, however, necessarily also involves the abolishment of "dormant" discriminatory laws.

Outside the realm of the law, the struggle for gay rights is part of the general struggle to promote a "human rights culture" with genuine respect for others' right to exist, enjoy equal rights and express themselves.

As this chapter has documented, there have been many and profound changes in general views on homosexuality and the scope of "gay rights" in recent years. The Zimbabwe Book Fair drama is not the end of the road, but by putting the issue so firmly on the agenda it may mark the beginning of a new road. 


\section{Appendix 1}

\section{AIDS and homosexuality-getting the facts straight}

Homosexuality has been branded as equal to and as the cause of AIDS in some statements in the debate. Clearly AIDS is a highly emotive disease, as it often involves both sexuality and death. But this kind of statement does nothing to help the victims of AIDS, the fight against the disease, nor of course does it contribute to a rational approach to homosexuality. AIDS is too serious to be used as a cheap ploy in a debate, and a few facts are need to set the discussion straight:

- Although an AIDS epidemic has hit the male homosexual community in North America hard, the transmission in Africa is almost invariably heterosexual. Sub-Saharan Africa has, according to World Health organisation estimates, more HIVinfected individuals than any other part of the world ( 8 million 1995).

- The HIV virus which breaks down the immunity system, and causes the AIDS disease, is transmitted sexually, or through the blood of an infected woman to her unborn child, or (to a limited degree) when infected blood is transfused.

- Although AIDS is classified as a sexually transmitted disease, the epidemics cannot be explained only by sexual behaviour patterns. Infection does presuppose more than one sexual partner, but the virus can live for many years in an infected body before the AIDS disease develops.

- More important than the personal lifestyle of individuals is the broader social pattern, with labour migration, for example, leading men and women to live apart from their partners for long periods and in squalid conditions. Wars and social upheaval also contribute to the spread of the disease.

- The HIV virus does not spread easily, but requires direct blood to blood or sexual fluids to blood contact, which is facilitated when people are in poor health, or have damaged membranes, particularly in areas where other sexually transmitted diseases are commonplace and have not been tended to. AIDS is a poverty disease, although the pattern in Africa often is that of men with money exploiting women who need money.

- Nobody knows where the virus first developed (probably through a mutation of virus cells). The first documented epidemics of AIDS involved homosexuals in North America, where the virus spread because of a combination of multiple partners and sensitive membranes in anal sex.

- The gay community is the only group which has markedly changed their sexual behaviour because of the AIDS epidemics. The gay community has also been a pioneer in home-based care and hospice care for AIDS patients.

(This summary is based on AIDS i Afrika (AIDS in Africa), Mai Palmberg ed., published by the Nordic Africa Institute 1993) 


\section{Appendix 2}

\section{Address List}

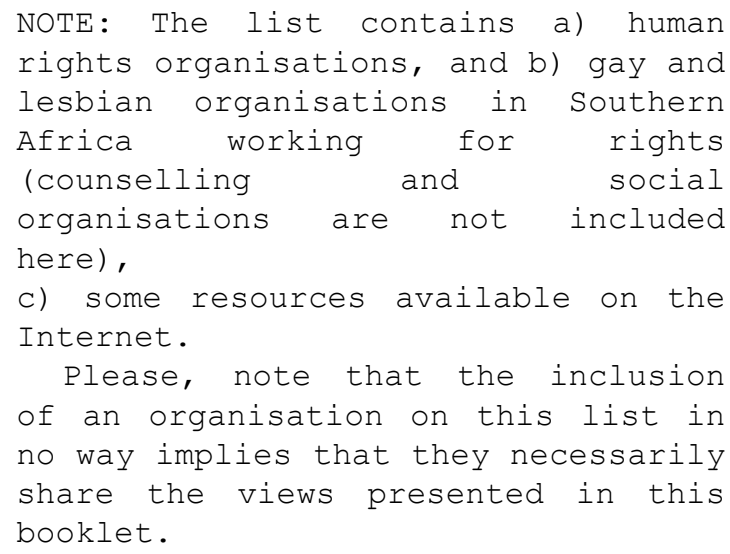

The Catholic Commission for Justice and Peace in Zimbabwe

P.O. Box 8493

Causeway

(street address: 31, Selous Avenue

Corner 4 th Street)

Harare

Zimbabwe

National Director: Mike Auret

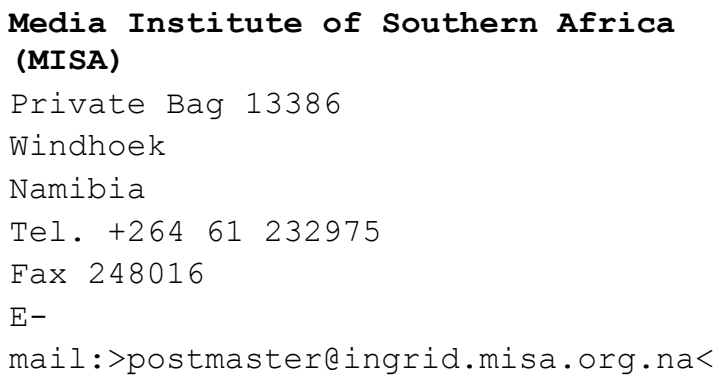

Zimbabwe Human Rights Association (ZimRights)

55 Herbert Chitepo Ave.

P.O. Box 3951

Harare

Zimbabwe

Tel. (263) - $4-738609$

$\operatorname{Fax}(263)-4-796589$

Legal Resources Foundation

P.O. Box 918

Harare

Zimbabwe

Tel. (263) - 4 - 728 211/2

$\operatorname{Fax}(263)-4-728213$ 


\section{Gay rights organisations}

National Coalition for Gay and Lesbian Equality (NCGLE)

(Launched in 1994 as a pressure group in the constitutional debate) P.O. Box 1984

Joubert Park 2044

Johannesburg

South Africa

Tel. (011) 4033835

Fax (011) 3397762
Gays and Lesbians of Zimbabwe (GALZ)

Private Bag A6131

Avondale

Harare

Zimbabwe

The Equality Foundation

P.O. Box 87722

Houghton

2041

South Africa

Lawyers for gay and lesbian equality

c/o Centre for Applied Legal Studies

University of Witwatersrand

Private Bag X3

Witwatersrand

2050

South Africa

Tel. (011) 403-6918

Fax (011) 403-2341

International Gay and Lesbian Human Rights Commission

1360 Mission St, Ste 200

San Francisco, CA 94103

USA

Phone: +1-415-255-8680

Fax: +1-415-255-8662

Email: iglhrceigc.apc.org

(The International Gay and Lesbian Human Rights Commission is a nonprofit humanitarian organization that monitors, documents, and mobilizes responses to human rights violations against lesbians, gay men, bisexuals, the transgendered, and people with HIV and AIDS worldwide.)

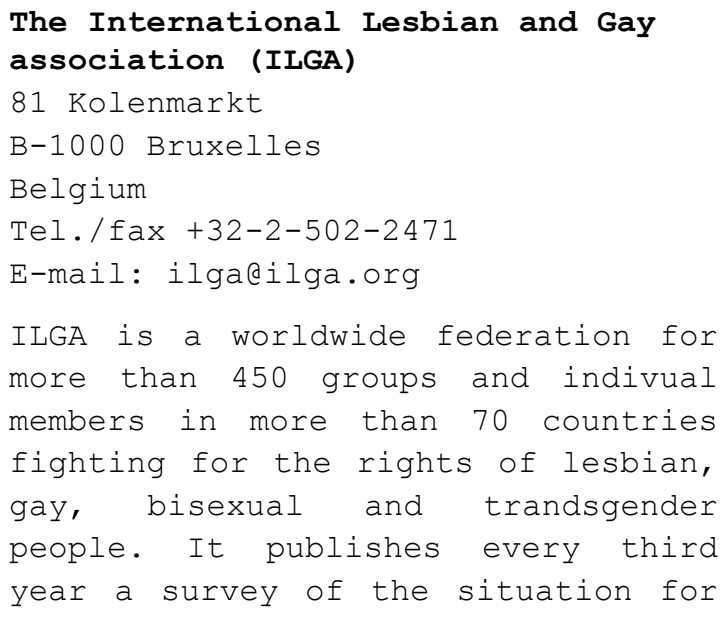


lesbians and gays in the world, the Pink Book.

\section{Internet Resources}

The following Internet mailing lists

(to which subscribers enter
material) convey useful material and up-dates on the global development of gay rights as a human rights issue:

Queerplanet (on general development and discussion)

Queerlaw (on legal development and protection)

To subscribe you write to >majordomodabacus. oxy.edu< and enter into the mail message only the words:

subscribe queerplanet

(or) subscribe queerlaw

A website on various homosexual issues, including legal development and protection with links to a great number of other sites is the queer Resources Directory:

http://www. qrd.org/QRD/www/index.htm 1 . 